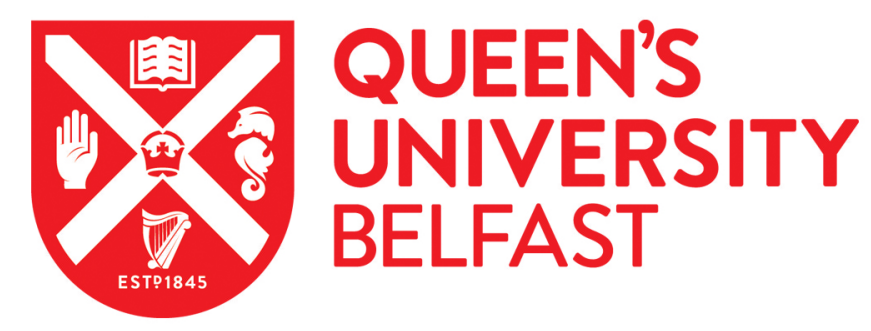

\title{
Arene-polyfluoroarene $\pi-\pi$ stacking between N-heterocyclic carbene ligands of pentamethylcyclopentadienyl group 9 metal complexes
}

Lockley, A. J., Marr, A. C., Saunders, G. C., \& Thomas, H. P. (2019). Arene-polyfluoroarenem-ா stacking between $\mathrm{N}$-heterocyclic carbene ligands of pentamethylcyclopentadienyl group 9 metal complexes. Journal of Fluorine Chemistry. https://doi.org/10.1016/j.jfluchem.2019.01.006

Published in:

Journal of Fluorine Chemistry

Document Version:

Peer reviewed version

Queen's University Belfast - Research Portal:

Link to publication record in Queen's University Belfast Research Portal

Publisher rights

Copyright 2019 Elsevier

This manuscript is distributed under a Creative Commons Attribution-NonCommercial-NoDerivs License

(https://creativecommons.org/licenses/by-nc-nd/4.0/), which permits distribution and reproduction for non-commercial purposes, provided the author and source are cited.

\section{General rights}

Copyright for the publications made accessible via the Queen's University Belfast Research Portal is retained by the author(s) and / or other copyright owners and it is a condition of accessing these publications that users recognise and abide by the legal requirements associated with these rights.

Take down policy

The Research Portal is Queen's institutional repository that provides access to Queen's research output. Every effort has been made to ensure that content in the Research Portal does not infringe any person's rights, or applicable UK laws. If you discover content in the Research Portal that you believe breaches copyright or violates any law, please contact openaccess@qub.ac.uk. 


\section{Accepted Manuscript}

Title: Arene-polyfluoroarene $\pi-\pi$ stacking between $\mathrm{N}$-heterocyclic carbene ligands of pentamethylcyclopentadienyl group 9 metal complexes

Authors: Alistair J. Lockley, Andrew C. Marr, Graham C. Saunders, Hayden P. Thomas

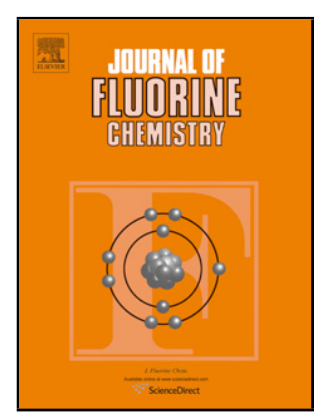

PII: S0022-1139(18)30471-8

DOI:

Reference: https://doi.org/10.1016/j.jfluchem.2019.01.006

To appear in: $\quad$ FLUOR

Received date: $\quad 21$ November 2018

Revised date: 20 January 2019

Accepted date: $\quad 20$ January 2019

Please cite this article as: Lockley AJ, Marr AC, Saunders GC, Thomas HP, Arene-polyfluoroarene $\pi-\pi$ stacking between N-heterocyclic carbene ligands of pentamethylcyclopentadienyl group 9 metal complexes, Journal of Fluorine Chemistry (2019), https://doi.org/10.1016/j.jfluchem.2019.01.006

This is a PDF file of an unedited manuscript that has been accepted for publication. As a service to our customers we are providing this early version of the manuscript. The manuscript will undergo copyediting, typesetting, and review of the resulting proof before it is published in its final form. Please note that during the production process errors may be discovered which could affect the content, and all legal disclaimers that apply to the journal pertain. 
Arene-polyfluoroarene $\pi$ - $\pi$ stacking between N-heterocyclic carbene ligands of pentamethylcyclopentadienyl group 9 metal complexes

Alistair J. Lockley, ${ }^{\mathrm{a}}$ Andrew C. Marr, ${ }^{\mathrm{b}}$ Graham C. Saunders ${ }^{\mathrm{a},{ }^{*}}$ and Hayden P. Thomas ${ }^{\mathrm{a}}$

${ }^{b}$ School of Chemistry and Chemical Engineering, Queen's University Belfast, Belfast BT9 $5 A G$, United Kingdom

${ }^{a}$ School of Science, University of Waikato, Private Bag 3105, Hamilton 3240, New Zealand

Graphical abstract

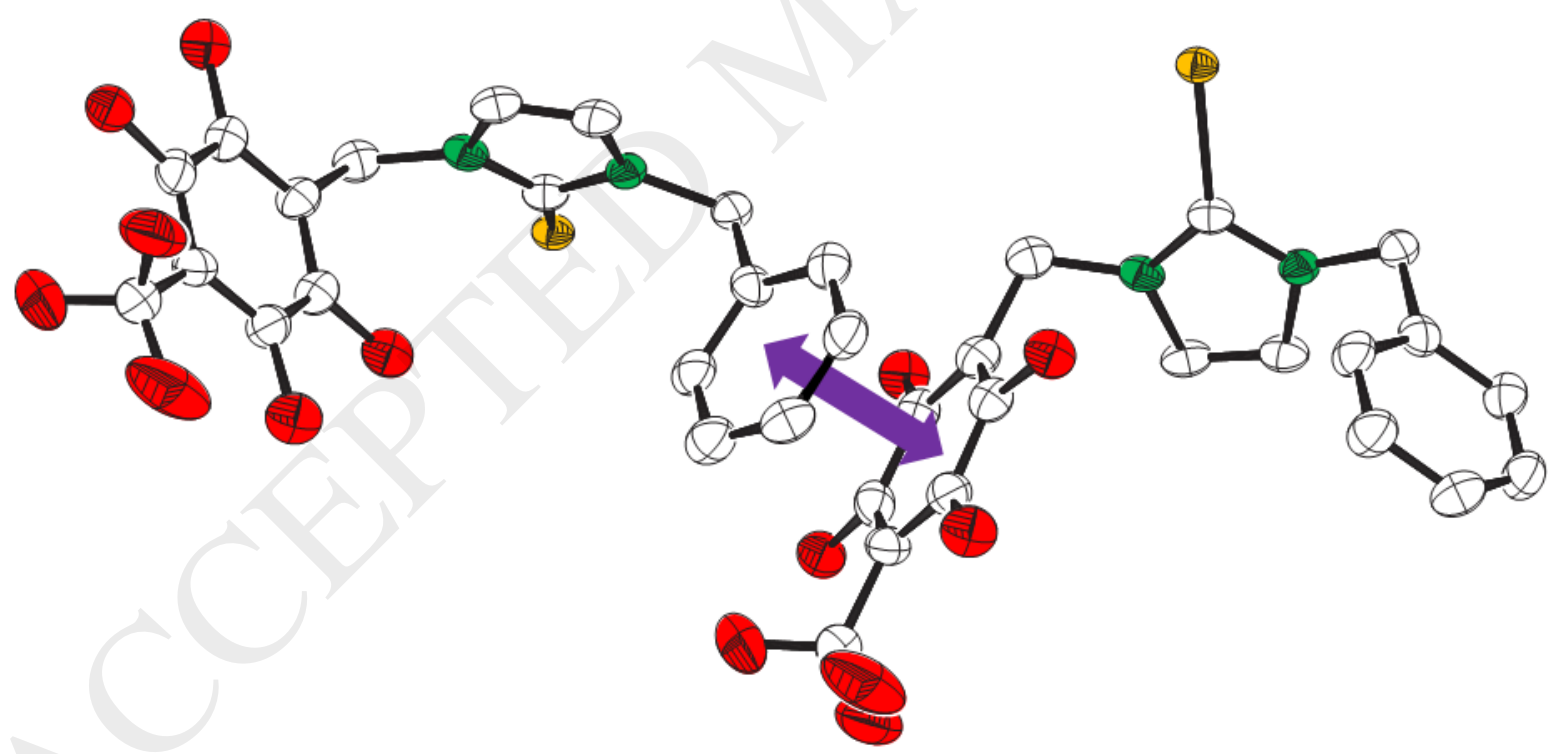

\section{Highlights}

- The crystal structures of the dichloromethane solvates of $\left(\eta^{5}\right.$ pentamethylcyclopentadienyl)rhodium(кC-1-(4-trifluoromethyl-2,3,5,6- 
tetrafluorophenylmethyl)-3-benzylimidazol-2-ylidene) dichloride and its iridium analogue contain intermolecular $\pi-\pi$ stacking.

- The crystal structures of the dichloromethane solvates of $\left(\eta^{5}\right.$ pentamethylcyclopentadienyl)rhodium( $\kappa \mathrm{C}-1-(2,3,4,5,6$-pentafluorophenylmethyl)-3benzylimidazol-2-ylidene) dichloride and its iridium analogue contain intermolecular lone pair $-\pi$ interactions.

- The crystals structures possess hydrogen-bonding between the complex and dichloromethane molecules.

- The strengths of the interactions have been probed by DFT calculations.

- The presence of $\pi-\pi$ stacking or lone pair $-\pi$ interactions, which are of approximately the same strength, is determined by the steric requirements of the para moiety: fluorine or trifluoromethyl.

\section{Abstract -}

( $\eta^{5}$-Pentamethylcyclopentadienyl)rhodium( $\kappa \mathrm{C}-1-(2,3,4,5,6$-pentafluorophenylmethyl)-3-

benzylimidazol-2-ylidene) dichloride (1a) and its iridium analogue (1b) crystallize as dichloromethane solvates in the enantiomorphous space group $P 2_{1} 2_{1} 2_{1}$. $\quad\left(\eta^{5}-\right.$ Pentamethylcyclopentadienyl)rhodium( $\kappa \mathrm{C}$-1-(4-trifluoromethyl-2,3,5,6-tetrafluorophenylmethyl)-3benzylimidazol-2-ylidene) dichloride (2a) and its iridium analogue (2b) crystallize as dichloromethane solvates in the polar space group $P$ ca2 $2_{1}$. All the crystal structures possess columns of alternating complex and dichloromethane molecules which are linked by hydrogen bonding. Perpendicular to these is hydrogen bonding between the imidazol-2-ylidene hydrogen atoms and chloride ligands. The crystal structures of $\mathbf{2} \mathbf{a}$ and $\mathbf{2} \mathbf{b}$ also display intermolecular $\pi-\pi$ stacking between 
the phenyl and trifluoromethyltetrafluorophenyl rings of molecules in a direction perpendicular to the columns and hydrogen bonding between the complex molecules. In contrast those of $\mathbf{1 a}$ and $\mathbf{1 b}$ display intermolecular lone pair- $\pi$ interactions in the same direction as the hydrogen bonding between the complex molecules. DFT calculations reveal that the $\pi-\pi$ stacking and lone pair $-\pi$ interactions are of approximately the same energy. The difference in the structures arises from the steric requirements of the trifluoromethyl group.

Keywords

$\mathrm{N}$-Hetrocyclic carbene, crystal structure, $\pi-\pi$ stacking, lone pair $-\pi$ interaction

\section{Introduction}

The attractive interaction between parallel arene and polyfluoroarene rings, commonly termed $\pi-\pi$ stacking, has been known for five decades [1]. Until recently its use in crystal engineering had been restricted to relatively simple molecules [2], but more recently more elaborate systems that allowed the crystal engineering of crystal structures with particular properties, such as polarity, have been devised [3]. In particular, aryl- and polyfluoroaryl-substituted imidazolium salts have proved to be fruitful [4-7]. For example, 1-(2,3,4,5,6-pentafluorophenylmethyl)-3-benzylimidazolium bromide [4] and 1-(4-chloro-2,3,5,6-tetrafluorophenyl)-3-benzylimidazolium bromide [6] crystallize in the polar space groups $P 1$ and $C$ c respectively. Imidazolium salts are precursors to $\mathrm{N}$-heterocycle carbenes, and so it is reasonable to expect that $\pi-\pi$ stacking between the aryl and polyfluoroaryl substituents of NHCs coordinated to metals would also occur. The crystal structures of very few metal complexes of NHCs bearing both aryl- and polyfluoroaryl substitutents have been reported [8-10], and none possess intermolecular $\pi-\pi$ stacking between the complementary rings, although trans$\left[\mathrm{PdBr}_{2}\left(\kappa \mathrm{C}-\mathrm{C}_{6} \mathrm{H}_{5} \mathrm{CH}_{2} \mathrm{NC}_{3}\left(\mathrm{C}_{4} \mathrm{H}_{4}\right) \mathrm{NCH}_{2} \mathrm{C}_{6} \mathrm{~F}_{5}\right)_{2}\right]$ does display intramolecular $\pi-\pi$ stacking [9]. 


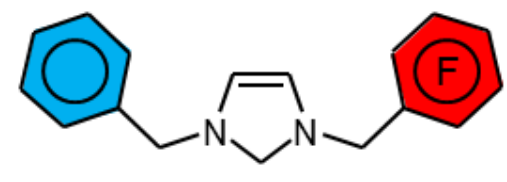

I

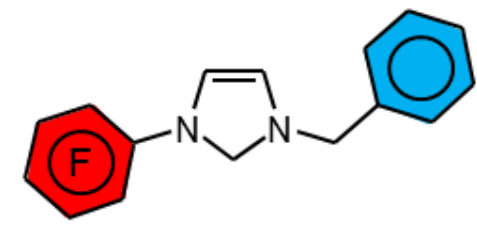

II

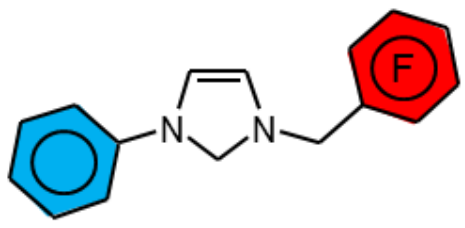

III

Figure 1. Aryl and polyfluoroaryl-substituted NHC ligands

Complexes of 1-perfluoroarylmethyl-3-benzylimidazol-2-ylidene (I) (Figure 1) provide a rational area of study because the crystal structures of the precursor imidazolium salts possess $\pi-\pi$ stacking $[4,6,11,12]$, and because complexes of 1-polyfluoroaryl-3-arylmethylimidazol-2-ylidene (II) undergo undesired reactions in their syntheses [13], and the sole example of an imidazolium salt that is a precursor to 1-polyfluoroarylmethyl-3-arylimidazol-2-ylidene (III) does not possess $\pi-\pi$ stacking [7]. Consequently a structural study of ( $\eta^{5}$-pentamethylcyclopentadienyl)rhodium and iridium complexes of 1-(2,3,4,5,6-pentafluorophenylmethyl)-3-benzylimidazol-2-ylidene and its analogue 1(4-trifluoromethyl-2,3,5,6-tetrafluorophenylmethyl)-3-benzylimidazol-2-ylidene,

$\left[\left(\eta^{5}-\right.\right.$ $\left.\left.\mathrm{C}_{5} \mathrm{Me}_{5}\right) \mathrm{MCl}_{2}\left(\kappa \mathrm{C}-\mathrm{C}_{6} \mathrm{H}_{5} \mathrm{CH}_{2} \mathrm{NC}_{3} \mathrm{H}_{2} \mathrm{NCH}_{2} \mathrm{C}_{6} \mathrm{~F}_{4} \mathrm{X}\right)\right]\left(\mathbf{X}=\mathrm{F}, 2 \mathrm{X}=\mathrm{CF}_{3} ; \mathbf{a} \mathrm{M}=\mathrm{Rh}, \mathbf{b} \mathrm{M}=\mathrm{Ir}\right)$ was undertaken. Here are reported the results of the study, augmented by a DFT study.

\section{Results and discussion}

The complexes $\left[\left(\eta^{5}-\mathrm{C}_{5} \mathrm{Me}_{5}\right) \mathrm{MCl}_{2}\left(\kappa \mathrm{C}-\mathrm{C}_{6} \mathrm{H}_{5} \mathrm{CH}_{2} \mathrm{NC}_{3} \mathrm{H}_{2} \mathrm{NCH}_{2} \mathrm{C}_{6} \mathrm{~F}_{4} \mathrm{X}\right)\right]\left(\mathbf{1} \mathrm{X}=\mathrm{F} ; \mathbf{2} \mathrm{X}=\mathrm{CF}_{3} ; \mathbf{a}\right.$ $\mathrm{M}=\mathrm{Rh} ; \mathbf{b} \mathrm{M}=\mathrm{Ir}$ ) were prepared by transfer of the NHC ligand from the respective silver complexes. Recrystallization from dichloromethane yielded crystals of the monosolvates. The complexes, which are chiral by virtue of possessing different substituents on the NHC ligand, crystallized in noncentrosymmetric space groups in the orthorhombic crystal system; $\mathbf{1 a}$ and $\mathbf{1 b}$ as conglomerates in the enantiomorphous space group $P 2_{1} 2_{1} 2_{1}$, and $\mathbf{2 a}$ and $\mathbf{2 b}$ as true racemates in the polar space group 
$P$ ca2 ${ }_{1}$. Crystal data are given in Table 1 and selected distances and angles are given in Table 2 . The bond distances and dihedral angles are virtually identical to those of the optimized structures of the rhodium complexes for gas phase molecules calculated using the $\omega \mathrm{B} 97 \mathrm{X}-\mathrm{D}$ [14] method and the 6$311 \mathrm{G}++(2 \mathrm{~d}, 2 \mathrm{p})$ basis set. The structures of 1a (Figure 2) and 2a (Figure 3) are similar, but show differences in the positions of the phenyl and polyfluoroaryl rings (Figure 4). The iridium complexes, $\mathbf{1 b}$ and $\mathbf{2 b}$, are isostructural with their rhodium analogues.

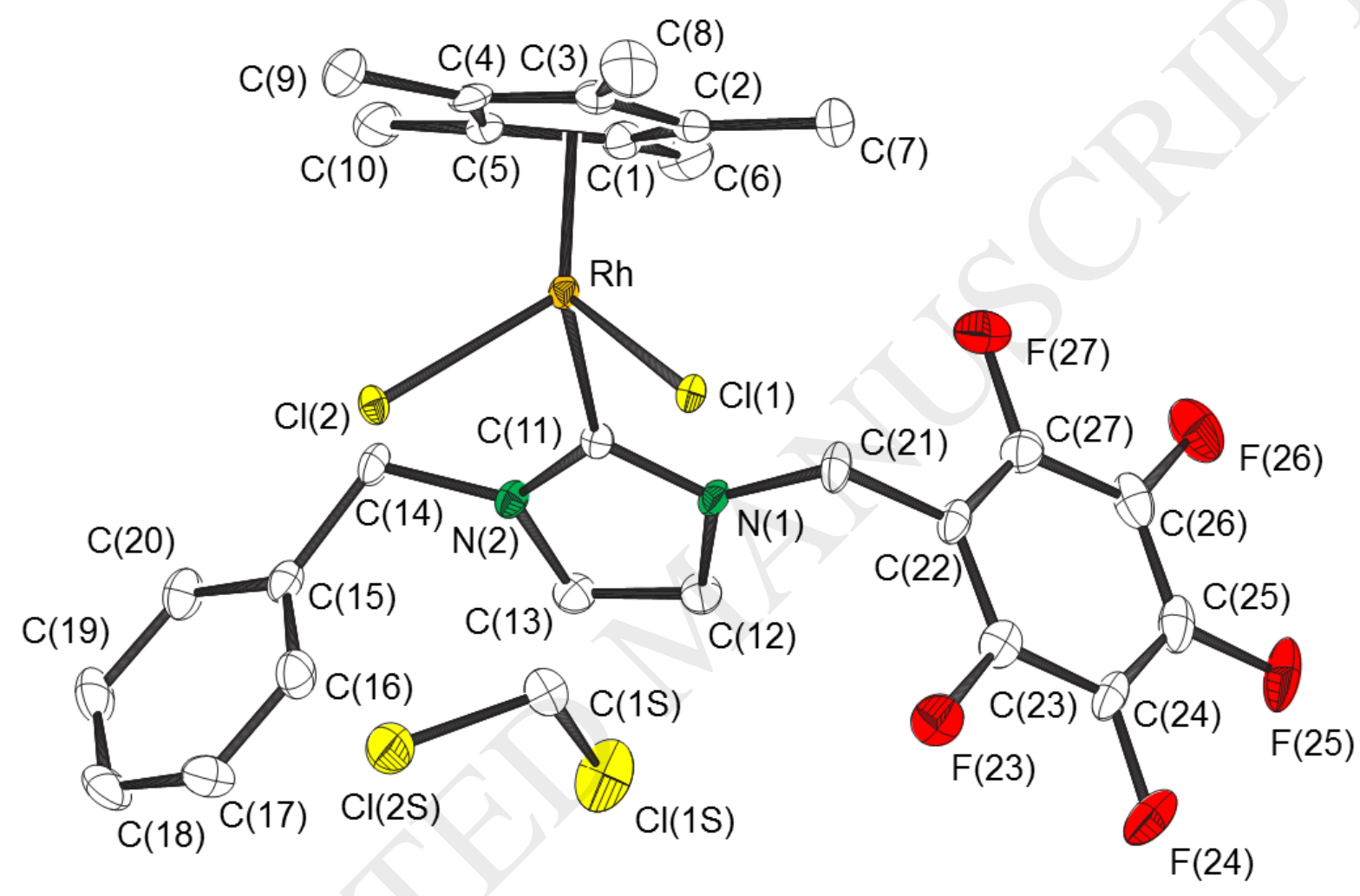

Figure 2. The structure of complex 1a showing the position of the closest molecule of dichloromethane. Thermal ellipsoids are at the 50\% level. Hydrogen atoms are omitted for clarity. 


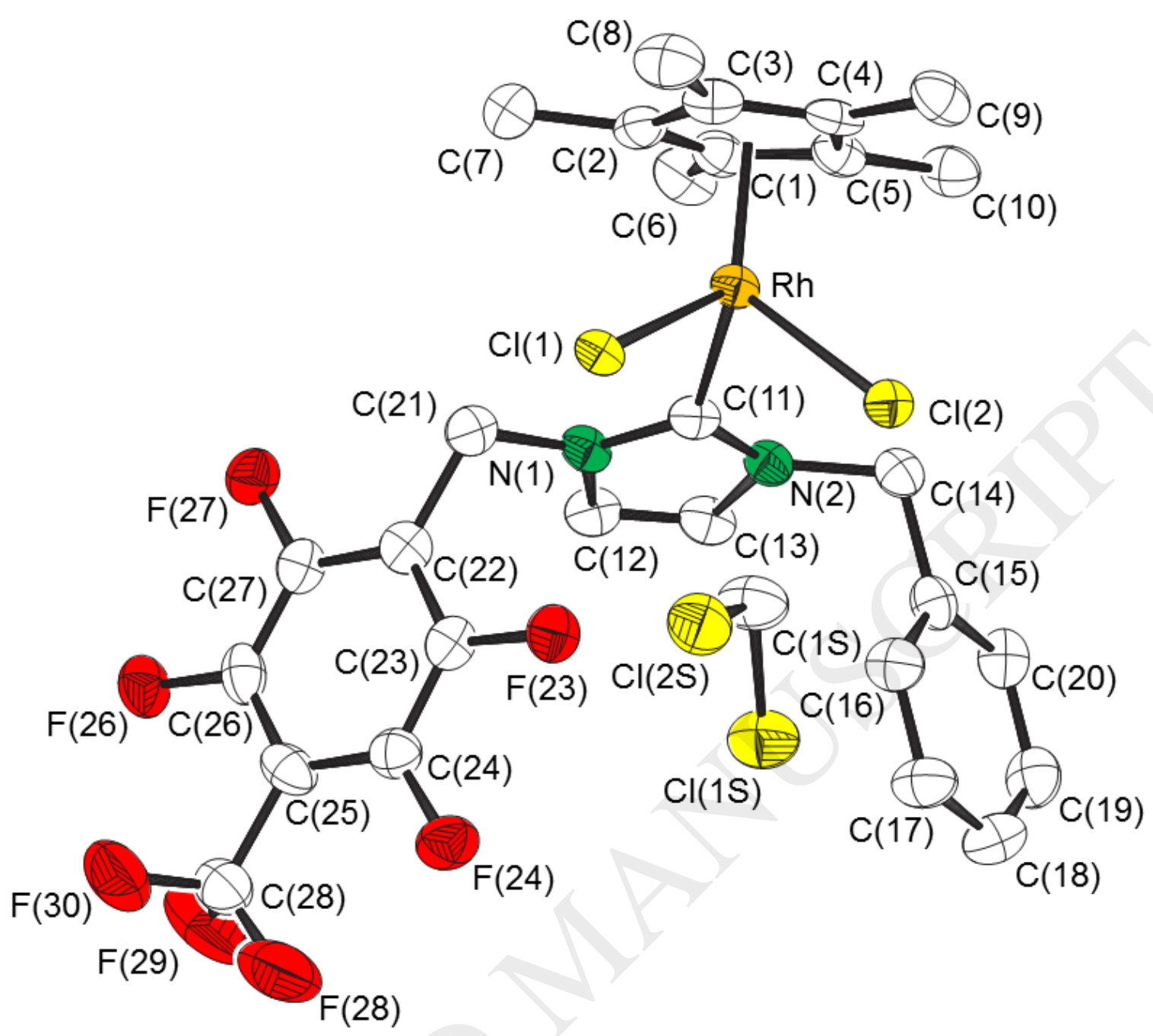

Figure 3. The structure of $\mathbf{2 a}$ showing the position of the closest molecule of dichloromethane. Thermal ellipsoids are at the $50 \%$ level. Hydrogen atoms are omitted for clarity. 


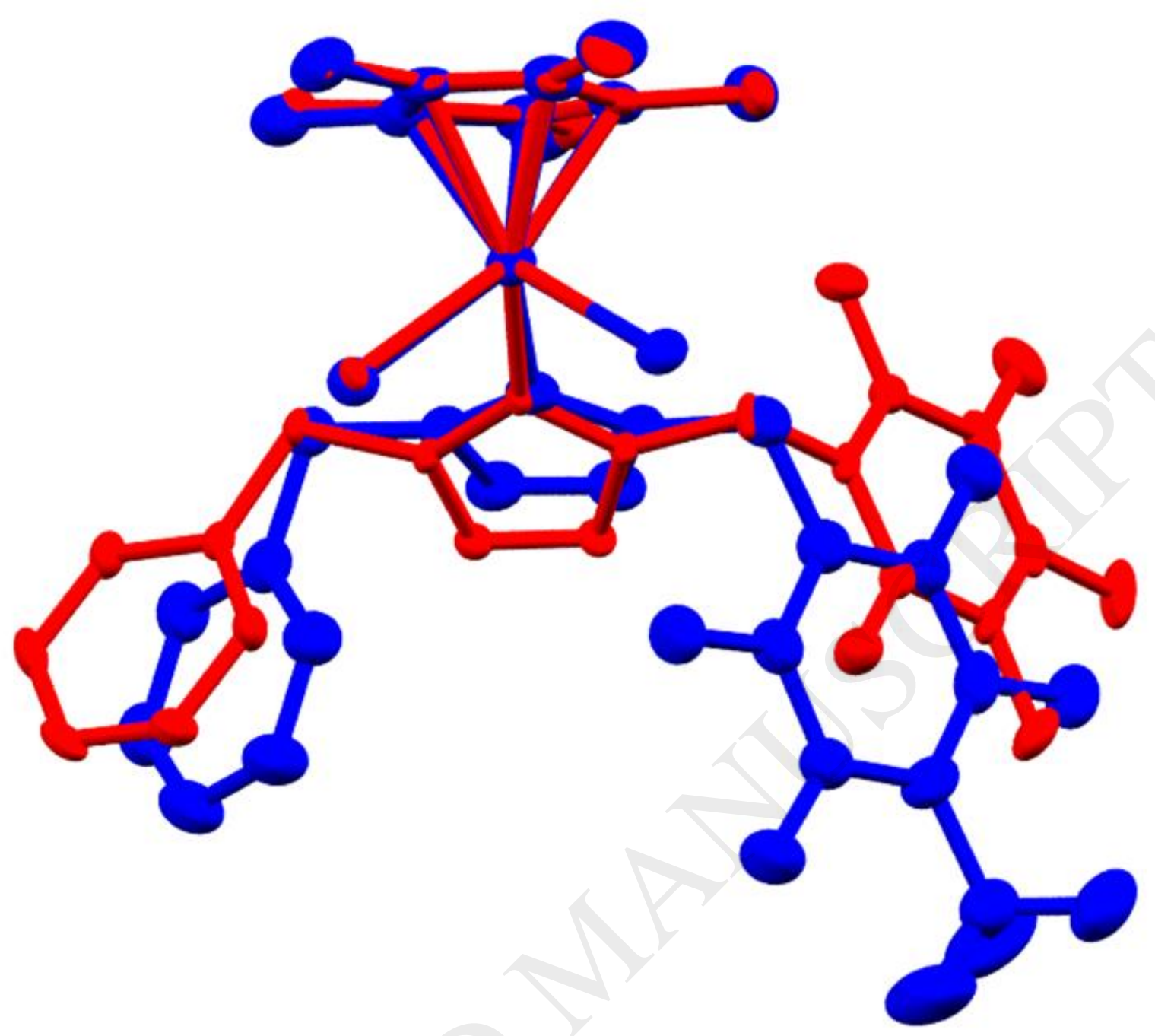

Figure 4. Overlay of the structures of complex $\mathbf{1 a}(\mathrm{red})$ and complex $\mathbf{2 a}$ (blue).

The crystal structures comprise columns of alternating complex and solvent molecules (parallel to the $a$ axis for $\mathbf{1 a}$ and $\mathbf{1 b}$, and parallel to the $b$ axis for $\mathbf{2 a}$ and $\mathbf{2 b}$ ) with the carbon atom of the closest dichloromethane molecule close to the chloride ligands of the complex (Figure 5). The geometric parameters suggest $\mathrm{Cl}_{2} \mathrm{CH}_{2} \cdots \mathrm{Cl}$ hydrogen bonding (Table 3). In particular the $\mathrm{C} \cdots \mathrm{Cl}$ distances are less than, or close to, $3.45 \AA$, the sum of the van der Waals' radii of carbon and chlorine [15]. The interactions were calculated to be attractive by 52 and $42 \mathrm{~kJ} \mathrm{~mol}^{-1}$ for $\mathbf{1 a}$ and $2 \mathbf{a}$ respectively. There are also short distances between one of the chlorine atoms of another molecule of dichloromethane and carbon atoms of the pentamethylcyclopentadienyl ligand (Figure 4). The 
geometric parameters suggest $\mathrm{CH}_{3} \cdots \mathrm{ClCH}_{2} \mathrm{Cl}$ hydrogen bonding and the possibility of lone pair$\pi$ interactions. In support, theoretical studies on the interactions between anions, such as triflate and tetrafluoroborate, and the cyclopentadienyl ring of the neutral complex $\left[\left(\eta^{5}-\mathrm{C}_{5} \mathrm{Me}_{5}\right) \operatorname{Ir}\left\{\eta^{6}-\right.\right.$ $\left.\mathrm{C}_{6} \mathrm{H}_{2}\left(\mathrm{O}_{2} \mathrm{BF}_{2}\right)_{2}\right\}$, which are attractive by $c a .100 \mathrm{~kJ} \mathrm{~mol}^{-1}$, show that these comprise both hydrogen bonding and anion $-\pi$ interactions [16]. The interactions in 1a and 2a were calculated to be attractive by 19 and $16 \mathrm{~kJ} \mathrm{~mol}^{-1}$ respectively.

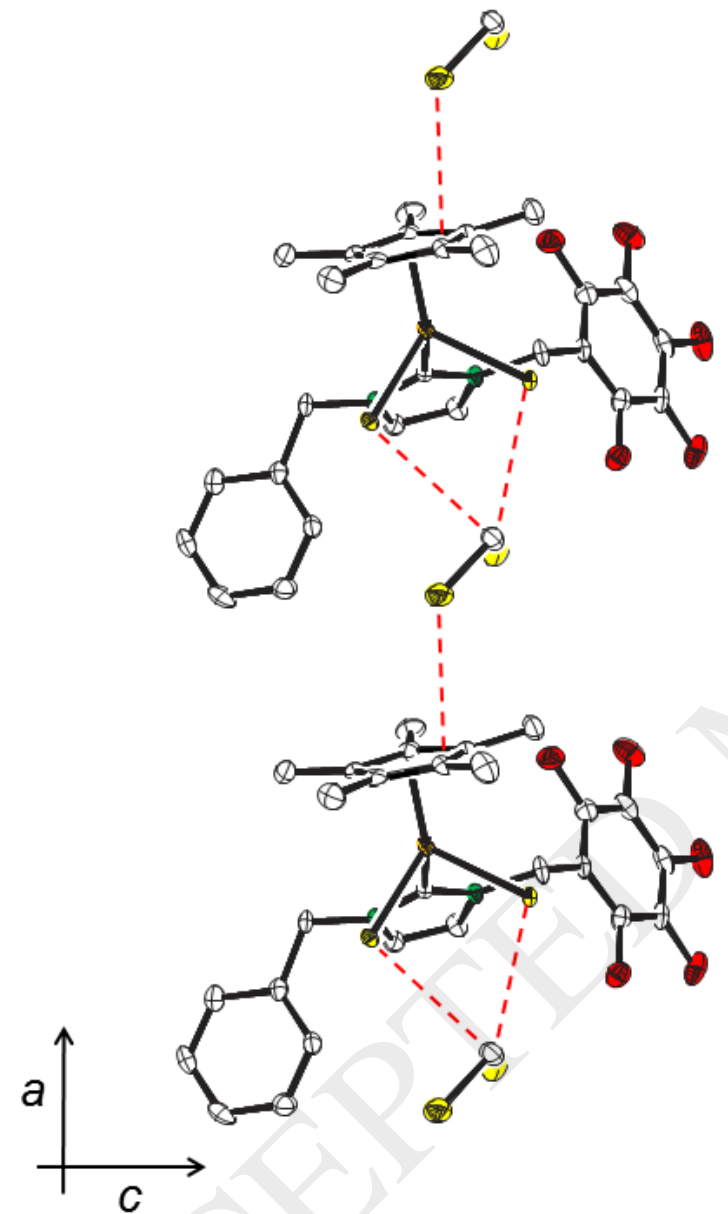

a)

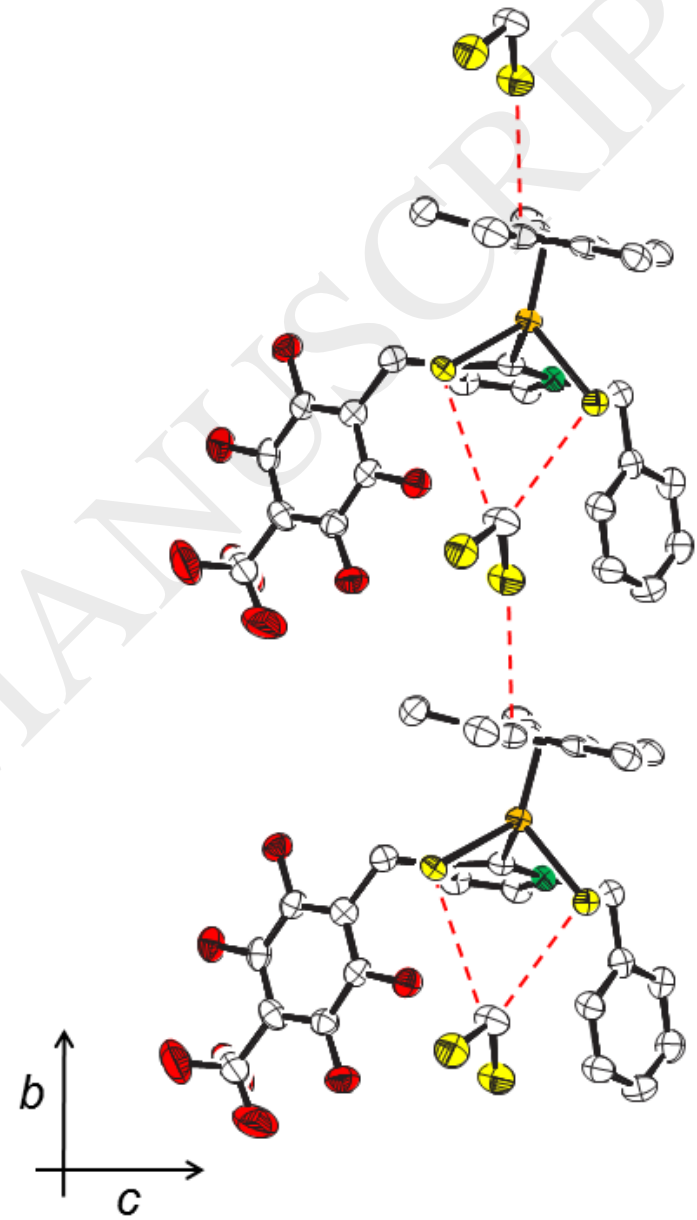

b)

Figure 5. The interactions between dichloromethane and (a) complex 1a and (b) complex 2a within a column of alternating complex and solvent molecules. Thermal ellipsoids are at the $50 \%$ level. Hydrogen atoms are omitted for clarity. 
The chloride ligands are also close to the imidazol-2-ylidene carbon atoms $\mathrm{C}(12)$ and $\mathrm{C}(13)$ of a complex molecule of an adjacent antiparallel column, although ca. $0.2 \AA$ further than from the carbon atom of the closest dichloromethane molecule (Table 4). These contacts link adjacent antiparallel columns parallel to the $b$ axis for $\mathbf{1 a}$ and $\mathbf{1 b}$ (Figure 6) and parallel to the $a$ axis for $\mathbf{2 a}$ and 2b (Figure 7). The number of atoms prevented calculations of the energies of these interactions for the complexes, but interactions between molecules of the 1,3-methyl substituted NHC complex $\left[\left(\eta^{5}-\right.\right.$ $\left.\left.\mathrm{C}_{5} \mathrm{Me}_{5}\right) \mathrm{RhCl}_{2}\left(\kappa \mathrm{C}-\mathrm{MeNC}_{3} \mathrm{H}_{2} \mathrm{NMe}\right)\right]$ using the atomic positions of $\mathbf{1 a}$ and $\mathbf{2 a}$ were calculated to be attractive by $51 \mathrm{~kJ} \mathrm{~mol}^{-1}$. For $\mathbf{1 a}$ and $\mathbf{1 b}$ the pentafluorophenyl ring of one molecule is also close to one of the chloride ligands of another, with distances that suggest a lone pair- $\pi$ interaction [17] (Table 4). The energy of the interaction between a molecule of $\mathbf{1 a}$ and pentafluorotoluene in the same relative position as the pentafluorobenzyl group of a second molecule of $\mathbf{1 a}$ was calculated to be $-38 \mathrm{~kJ} \mathrm{~mol}^{-1}$. Similar interactions are not present in the crystal structures of $\mathbf{2 a}$ and $\mathbf{2} \mathbf{b}$, with the chloride ligands being more distant and lying on normals to the rings' planes that are considerably outside the ring of carbon atoms. 


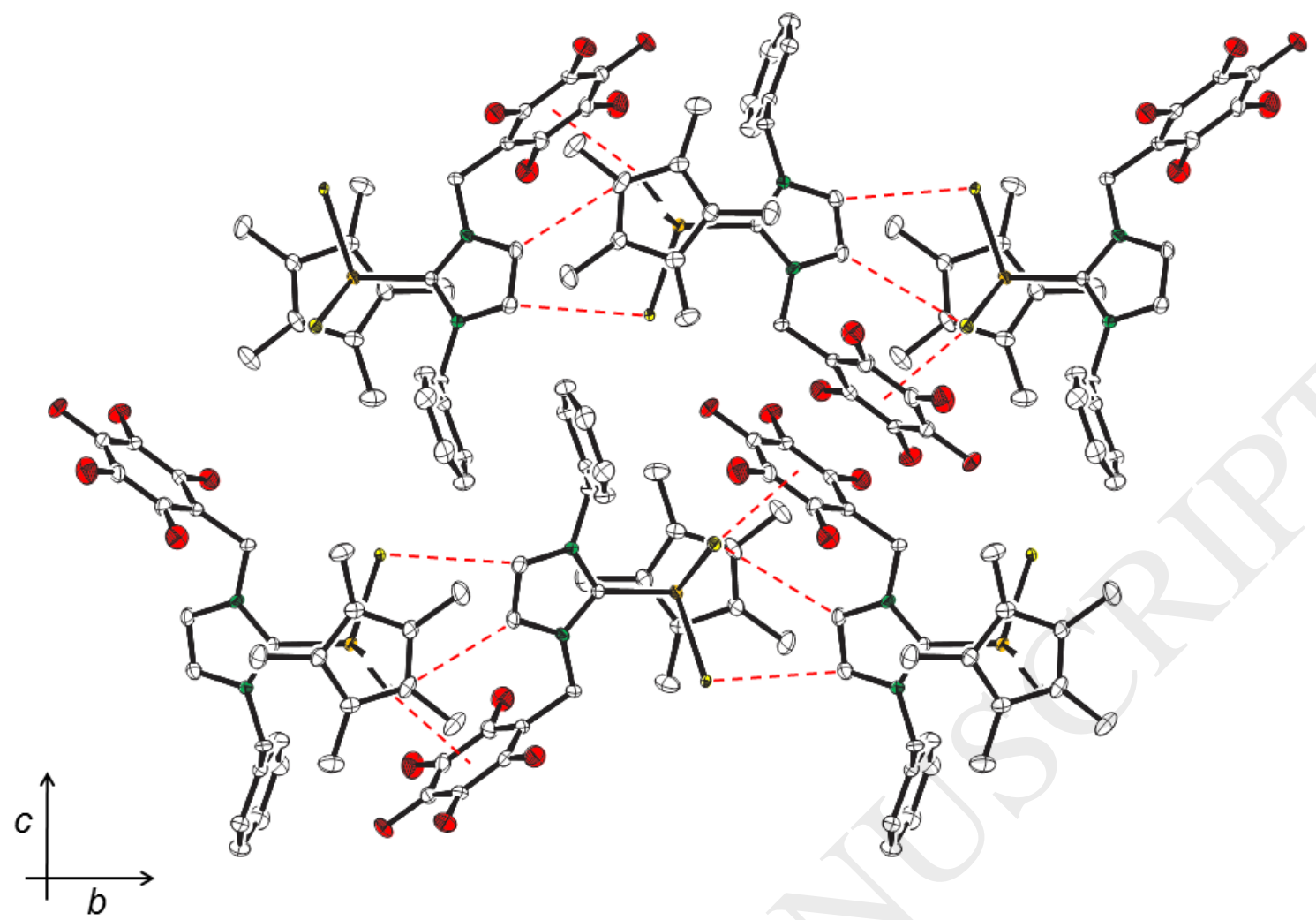

Figure 6. The crystal structure of complex 1a viewed parallel to the $a$ axis showing interactions between the molecules. Thermal ellipsoids are at the 50\% level. Dichloromethane molecules and hydrogen atoms are omitted for clarity. 


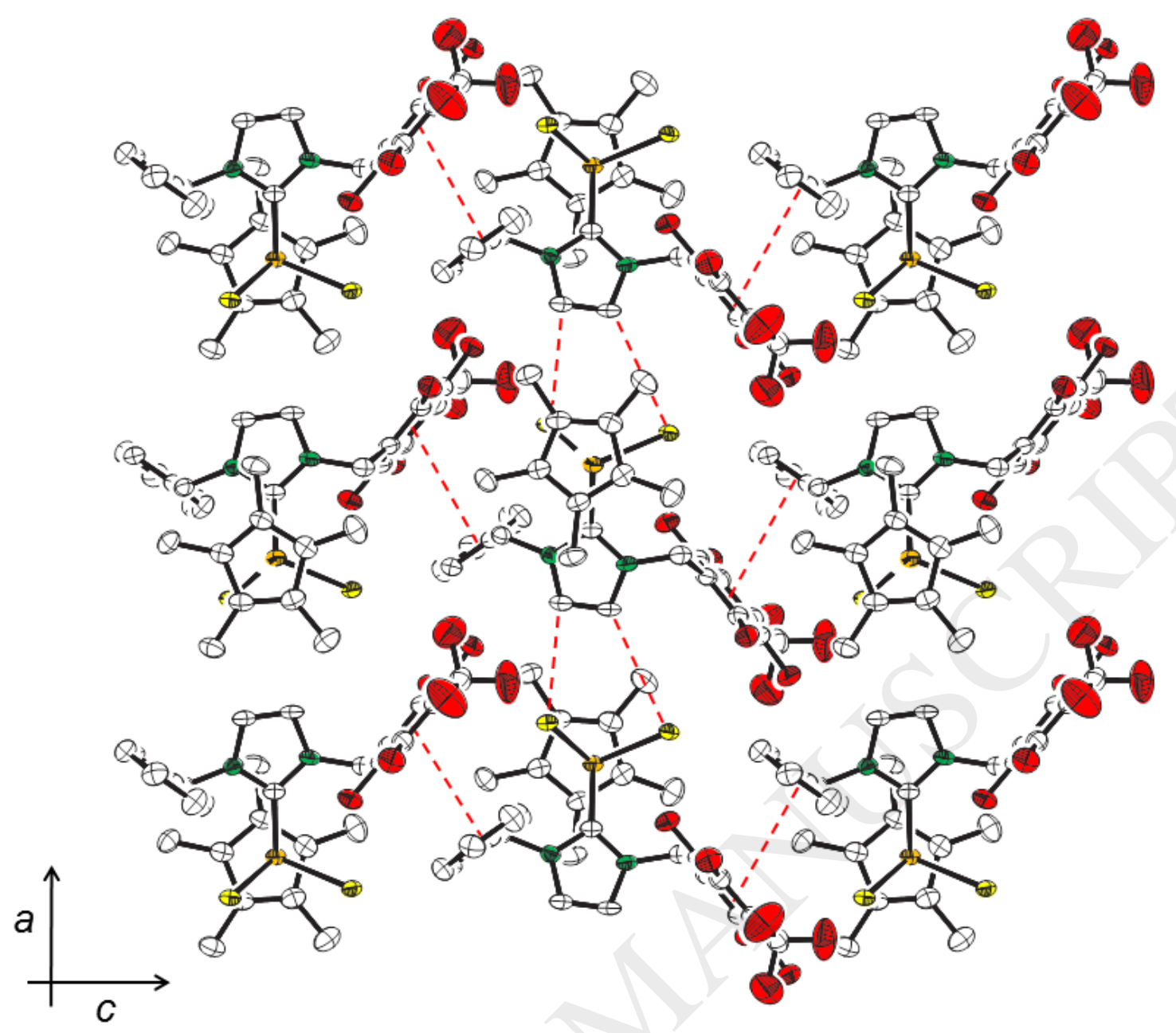

Figure 7. The crystal structure of complex 2a viewed parallel to the $b$ axis showing interactions between the molecules. Thermal ellipsoids are at the 50\% level. Dichloromethane molecules and hydrogen atoms are omitted for clarity.

In the crystal structures of $\mathbf{2 a}$ and $\mathbf{2} \mathbf{b}$ there is $\pi-\pi$ stacking between the perfluorotolyl group of one molecule and the phenyl ring of an adjacent molecule of opposite configuration, thereby linking the complex molecules of parallel columns to form chains parallel to the $c$ axis (Figure 7). The interactions between the molecules of $\mathbf{1 a}$ and 4-trifluoromethyl-2,3,5,6-tetrafluorotoluene and between 1a and toluene, with the positions of the atoms of the toluene molecules as for those of a second molecule of $\mathbf{2 a}$, were calculated to be attractive by 49 and $48 \mathrm{~kJ} \mathrm{~mol}^{-1}$ respectively, and that between 4-trifluoromethyl-2,3,5,6-tetrafluorotoluene and toluene was calculated to be attractive by 33 
$\mathrm{kJ} \mathrm{mol}^{-1}$, which is consistent with those calculated for the interaction between toluene and hexafluorobenzene at a separation of $3.4 \AA\left(-33.6\right.$ and $\left.-36.0 \mathrm{~kJ} \mathrm{~mol}^{-1}\right)[18] . \pi-\pi$ stacking is not evident in the crystal structures of $\mathbf{1 a}$ and $\mathbf{1 b}$.

The calculations strongly suggest that the absence or presence of $\pi-\pi$ stacking is not a result of the strengths of the interactions between the molecules, and certainly not as a result of $\pi-\pi$ stacking interactions being weaker than the other types of interaction. Rather it appears to be a consequence of the greater size of the trifluoromethyl group compared to the fluorine atom. The change of fluorine to trifluoromethyl (van der Waals' radii 1.47 [15] and $2.73 \AA$ [19] respectively) results in an increase in the unit cell volume of $c a .5 \%$, which arises predominantly from an increase in the unit cell length in only one direction; parallel to the hydrogen bonding interactions between complex molecules ( $b$ for $\mathbf{1 a}$ and $\mathbf{1 b}$ and $a$ for $\mathbf{2 a}$ and $\mathbf{2 b}$ ) (Table 1). The values of the other analogous unit cell lengths are very similar for the four crystal structures. The trifluoromethyl group shifts the perfluoroaryl ring from a position that allows the lone pair $-\pi$ interaction to one where $\pi-\pi$ stacking can occur, without significantly disrupting the other interactions or changing the packing efficiency, which is ca. $28 \%$ for all four crystal structures. Since the two interactions are of approximately the same strength the absence of one is compensated by the presence of the other.

\section{Conclusion}

Intermolecular $\pi-\pi$ stacking occurs between the complementary rings of $\left(\eta^{5}-\right.$ pentamethylcyclopentadienyl)rhodium( $\kappa \mathrm{C}$-1-(4-trifluoromethyl-2,3,5,6-tetrafluorophenylmethyl)-3benzylimidazol-2-ylidene) dichloride (2a), but not between those of ( $\eta^{5}$-pentamethylcyclopentadienyl)rhodium( $\kappa \mathrm{C}-1-(2,3,4,5,6$-pentafluorophenylmethyl)-3benzylimidazol-2-ylidene) dichloride (1a). Calculations reveal that hydrogen bonding interactions between complex molecules and between complex and dichloromethane molecules are stronger than the $\pi-\pi$ stacking interaction, and give rise to similar non-centrosymmetric arrangements of molecules of 1a and 2a, although with different space groups. The lack of $\pi-\pi$ stacking in 1a is ascribed to the 
presence of a lone pair $-\pi$ interaction between a chloride ligand and the pentafluorophenyl ring, which is of similar strength to a $\pi-\pi$ stacking interaction. The presence of a trifluoromethyl group in 2a prevents this interaction for steric reasons and as a consequence the phenyl and polyfluorotolyl rings align to facilitate $\pi-\pi$ stacking.

\section{Experimental}

\subsection{Instrumentation}

The ${ }^{1} \mathrm{H},{ }^{13} \mathrm{C}\left\{{ }^{1} \mathrm{H}\right\}$ and ${ }^{19} \mathrm{~F}$ NMR spectra were recorded in deuterochloroform, except where stated otherwise, using Bruker DRX300 or DPX400 spectrometers. ${ }^{1} \mathrm{H}$ (300.13 or $400.14 \mathrm{MHz}$ ) were referenced internally using the residual proto solvent resonance relative to $\mathrm{SiMe}_{4}(\delta \quad 0),{ }^{13} \mathrm{C}\left\{{ }^{1} \mathrm{H}\right\}$ (75.48 or $100.61 \mathrm{MHz})$ externally to $\mathrm{SiMe}_{4}(\delta 0)$, and ${ }^{19} \mathrm{~F}(282.40 \mathrm{MHz})$ externally to $\mathrm{CFCl}_{3}(\delta 0)$. All chemical shifts are quoted in $\delta(\mathrm{ppm})$, using the high frequency positive convention, and coupling constants in Hz. Elemental analyses were carried out by the Campbell Microanalytical Laboratory, The University of Otago. Electrospray mass spectra were recorded on a Bruker Daltonics micrOTOF spectrometer.

\subsection{Materials}

The imidazolium salt $\left[\mathrm{C}_{6} \mathrm{H}_{5} \mathrm{CH}_{2} \mathrm{NC}_{3} \mathrm{H}_{3} \mathrm{NCH}_{2} \mathrm{C}_{6} \mathrm{~F}_{5}\right] \mathrm{Br}$ [4] and the complexes $\left[\left(\eta^{5}\right.\right.$ $\left.\left.\mathrm{C}_{5} \mathrm{Me}_{5}\right) \mathrm{RhCl}(\mu-\mathrm{Cl})\right]_{2}$ and $\left[\left(\eta^{5}-\mathrm{C}_{5} \mathrm{Me}_{5}\right) \operatorname{IrCl}(\mu-\mathrm{Cl})\right]_{2}[20]$ were prepared as previously described. 1Benzylimidazole, and silver(I) oxide (Aldrich), and 4-trifluoromethyltetrafluorophenylmethyl bromide (Apollo Scientific) were used as supplied.

\subsection{Preparation of 1-(4-trifluoromethyl-2,3,5,6-tetrafluorophenylmethyl)-3-methylimidazolium}

\section{bromide}

1-Benzylimidazole $(0.52 \mathrm{~g}, 3.3 \mathrm{mmol})$ was added to 4-trifluoromethyltetrafluorophenylmethyl bromide $(1.02 \mathrm{~g}, 3.3 \mathrm{mmol})$ in dichloromethane $\left(50 \mathrm{~cm}^{3}\right)$. The mixture was left at ambient 
temperature for $166 \mathrm{~h}$. The solvent was removed by rotary evaporation yielding the product as a white solid. Yield $1.33 \mathrm{~g}$ (86\%). [M $-\mathrm{Br}]^{+}:\left[\mathrm{C}_{18} \mathrm{H}_{12} \mathrm{~F}_{7} \mathrm{~N}_{2}\right]^{+}$requires 389.0889; found 389.0942. $\delta_{\mathrm{H}}$ $\left(\left(\mathrm{CD}_{3}\right)_{2} \mathrm{SO}\right): 9.51\left(1 \mathrm{H}, \mathrm{s}, \mathrm{N}_{2} \mathrm{CH}\right), 7.88(1 \mathrm{H}, \mathrm{CH}), 7.84(1 \mathrm{H}, \mathrm{s}, \mathrm{CH}), 7.43\left(5 \mathrm{H}, \mathrm{m}, \mathrm{C}_{6} \mathrm{H}_{5}\right), 5.76(2 \mathrm{H}, \mathrm{s}$, $\left.\mathrm{CH}_{2}\right), 5.46\left(2 \mathrm{H}, \mathrm{s}, \mathrm{CH}_{2}\right) . \delta_{\mathrm{F}}\left(\left(\mathrm{CD}_{3}\right)_{2} \mathrm{SO}\right):-55.7\left(3 \mathrm{~F}, \mathrm{t}, J_{\mathrm{FF}}=22 \mathrm{~Hz}, \mathrm{CF}_{3}\right),-139.2\left(2 \mathrm{~F}, \mathrm{~m}, \mathrm{C}_{6} \mathrm{~F}_{4}\right),-141.3$ $\left(2 \mathrm{~F}, \mathrm{~m}, \mathrm{C}_{6} \mathrm{~F}_{4}\right)$.

4.4 Preparation of ( $\kappa C$-1-perfluoroarylmethyl-3-benzylimidazol-2-ylidene)silver bromide The silver complexes $\left[\left(\kappa \mathrm{C}-\mathrm{C}_{6} \mathrm{H}_{5} \mathrm{CH}_{2} \mathrm{NC}_{3} \mathrm{H}_{2} \mathrm{NCH}_{2} \mathrm{C}_{6} \mathrm{~F}_{4} \mathrm{X}-4\right) \mathrm{AgBr}\right]\left(\mathrm{X}=\mathrm{F}, \mathrm{CF}_{3}\right)$ were prepared as described for [( $\left.\left.\kappa \mathrm{C}-\mathrm{MeNC}_{3} \mathrm{H}_{2} \mathrm{NCH}_{2} \mathrm{C}_{6} \mathrm{~F}_{5}\right) \mathrm{AgBr}\right]$ [21].

[( $\left.\left(\kappa \mathrm{C}-\mathrm{C}_{6} \mathrm{H}_{5} \mathrm{CH}_{2} \mathrm{NC}_{3} \mathrm{H}_{2} \mathrm{NCH}_{2} \mathrm{C}_{6} \mathrm{~F}_{5}\right) \mathrm{AgBr}\right]$ from $\left[\mathrm{C}_{6} \mathrm{H}_{5} \mathrm{CH}_{2} \mathrm{NC}_{3} \mathrm{H}_{3} \mathrm{NCH}_{2} \mathrm{C}_{6} \mathrm{~F}_{5}\right] \mathrm{Br}(0.54 \mathrm{~g}, 1.2 \mathrm{mmol})$ and silver(I) oxide (0.16 g, $0.7 \mathrm{mmol})$. Yield $0.43 \mathrm{~g}(71 \%)$. [M $-\mathrm{Br}]^{+}:\left[\mathrm{C}_{34} \mathrm{H}_{22}{ }^{107} \mathrm{AgF}_{10} \mathrm{~N}_{4}\right]^{+}$requires 783.0736; found 783.0679. $\delta_{\mathrm{H}}: 7.30\left(5 \mathrm{H}, \mathrm{m}, \mathrm{C}_{6} \mathrm{H}_{5}\right), 7.01\left(1 \mathrm{H}, \mathrm{d},{ }^{3} J_{\mathrm{HH}}=1.8 \mathrm{~Hz}, \mathrm{CH}\right), 6.94\left(1 \mathrm{H}, \mathrm{d},{ }^{3} J_{\mathrm{HH}}\right.$ $=1.8 \mathrm{~Hz}, \mathrm{CH}), 5.56\left(2 \mathrm{H}, \mathrm{s}, \mathrm{CH}_{2}\right), 5.35\left(2 \mathrm{H}, \mathrm{s}, \mathrm{CH}_{2}\right) . \delta_{\mathrm{F}}:-140.5\left(2 \mathrm{~F}, \mathrm{~m}, \mathrm{~F}_{\text {ortho }}\right),-151.0\left(1 \mathrm{~F}, \mathrm{t},{ }^{3} J_{\mathrm{FF}}=21\right.$ $\left.\mathrm{Hz}, \mathrm{F}_{\text {para }}\right),-159.7\left(2 \mathrm{~F}, \mathrm{~m}, \mathrm{~F}_{\text {meta }}\right)$.

$\left[\left(\kappa \mathrm{C}-\mathrm{C}_{6} \mathrm{H}_{5} \mathrm{CH}_{2} \mathrm{NC}_{3} \mathrm{H}_{2} \mathrm{NCH}_{2} \mathrm{C}_{6} \mathrm{~F}_{4} \mathrm{CF}_{3}-4\right) \mathrm{AgBr}\right]$ from $\left[\mathrm{C}_{6} \mathrm{H}_{5} \mathrm{CH}_{2} \mathrm{NC}_{3} \mathrm{H}_{3} \mathrm{NCH}_{2} \mathrm{C}_{6} \mathrm{~F}_{4} \mathrm{CF}_{3}-4\right] \mathrm{Br}(0.47 \mathrm{~g}, 1.0$ mmol) and silver(I) oxide (0.12 g, $0.5 \mathrm{mmol})$. Yield $0.50 \mathrm{~g}(87 \%)$. $[\mathrm{M}-\mathrm{Br}]^{+}:\left[\mathrm{C}_{36} \mathrm{H}_{22}{ }^{107} \mathrm{AgF}_{14} \mathrm{~N}_{4}\right]^{+}$ requires 883.0672; found 883.0547. $\delta_{\mathrm{H}}: 7.34\left(5 \mathrm{H}, \mathrm{m}, \mathrm{C}_{6} \mathrm{H}_{5}\right), 7.04\left(1 \mathrm{H}, \mathrm{d},{ }^{3} J_{\mathrm{HH}}=1.7 \mathrm{~Hz}, \mathrm{CH}\right), 6.97(1 \mathrm{H}$, $\left.\mathrm{d},{ }^{3} J_{\mathrm{HH}}=1.7 \mathrm{~Hz}, \mathrm{CH}\right), 5.62\left(2 \mathrm{H}, \mathrm{s}, \mathrm{CH}_{2}\right), 5.34\left(2 \mathrm{H}, \mathrm{s}, \mathrm{CH}_{2}\right) . \delta_{\mathrm{F}}:-56.5\left(3 \mathrm{~F}, \mathrm{t},{ }^{3} J_{\mathrm{FF}}=21.5 \mathrm{~Hz}, \mathrm{CF}_{3}\right),-$ $138.1\left(2 \mathrm{~F}, \mathrm{~m}, \mathrm{C}_{6} \mathrm{~F}_{4}\right),-138.6\left(2 \mathrm{~F}, \mathrm{~m}, \mathrm{C}_{6} \mathrm{~F}_{4}\right)$.

( $\eta^{5}$-pentamethylcyclopentadienyl)metal( $\kappa C$-1-perfluoroarylmethyl-3-benzylimidazol-2-ylidene) dichloride complexes $(\mathbf{1 a}-\mathbf{2 b})$

Complexes 1a, 1b, 2a and $\mathbf{2 b}$ were prepared as described for $\left[\left(\eta^{5}-\mathrm{C}_{5} \mathrm{Me}_{5}\right) \mathrm{RhCl}_{2}(\kappa \mathrm{C}-\right.$ $\left.\mathrm{MeNC}_{3} \mathrm{H}_{2} \mathrm{NCH}_{2} \mathrm{C}_{6} \mathrm{~F}_{5}\right)$ ] [21], and recrystallized from dichloromethane or dichloromethane and pentane. $1 \mathbf{a}$ from $\left.\left[\left(\eta^{5}-\mathrm{C}_{5} \mathrm{Me}\right)_{5}\right) \mathrm{RhCl}(\mu-\mathrm{Cl})\right]_{2}(0.097 \mathrm{~g}, 0.157 \mathrm{mmol})$ and $\left[\left(\kappa \mathrm{C}-\mathrm{C}_{6} \mathrm{H}_{5} \mathrm{CH}_{2} \mathrm{NC}_{3} \mathrm{H}_{2} \mathrm{NCH}_{2} \mathrm{C}_{6} \mathrm{~F}_{5}\right) \mathrm{AgBr}\right]$ (0.165 g, 0.314 mmol). Yield: $0.191 \mathrm{~g}(94 \%)$. Anal. Calc. for $\mathrm{C}_{27} \mathrm{H}_{26} \mathrm{Cl}_{2} \mathrm{~F}_{5} \mathrm{~N}_{2} \mathrm{Rh} .\left(\mathrm{CH}_{2} \mathrm{Cl}_{2}\right): \mathrm{C}, 45.9 ; \mathrm{H}$, 
3.85; N, 3.8. Found: C, 45.7; H, 3.85; N, 3.8\%. [M - Cl] $]^{+}\left[\mathrm{C}_{27} \mathrm{H}_{26}{ }^{35} \mathrm{ClF}_{5} \mathrm{~N}_{2} \mathrm{Rh}\right]^{+}$requires 611.0760; found: $611.0830 . \delta_{\mathrm{H}}: 7.37\left(5 \mathrm{H}, \mathrm{m}, \mathrm{C}_{6} \mathrm{H}_{5}\right), 6.77\left(1 \mathrm{H}, \mathrm{d},{ }^{3} J_{\mathrm{HH}}=2.0 \mathrm{~Hz}, \mathrm{CH}\right), 6.57\left(1 \mathrm{H}, \mathrm{d},{ }^{3} J_{\mathrm{HH}}=2.0 \mathrm{~Hz}\right.$, $\mathrm{CH}), 6.13\left(2 \mathrm{H}, \mathrm{m}, \mathrm{NCHHC}_{6} \mathrm{H}_{5}\right.$ and $\left.\mathrm{NCHHC}_{6} \mathrm{~F}_{5}\right), 5.58\left(1 \mathrm{H}, \mathrm{d},{ }^{2} J_{\mathrm{HH}}=15.8 \mathrm{~Hz}, \mathrm{NCH} H\right), 5.31(1 \mathrm{H}, \mathrm{d}$, $\left.{ }^{2} J_{\mathrm{HH}}=14.8 \mathrm{~Hz}, \mathrm{NCHH}\right), 1.69\left(15 \mathrm{H}, \mathrm{s}, \mathrm{CH}_{3}\right) . \delta_{\mathrm{C}}: 172.3\left(\mathrm{~d},{ }^{1} J_{\mathrm{RhC}}=57 \mathrm{~Hz}, \mathrm{RhCN}_{2}\right), 145.8\left(\mathrm{dm},{ }^{1} J_{\mathrm{CF}}=\right.$ $\left.250 \mathrm{~Hz}, \mathrm{C}_{6} \mathrm{~F}_{5}\right), 141.8\left(\mathrm{dm},{ }^{1} J_{\mathrm{CF}}=250 \mathrm{~Hz}, \mathrm{C}_{6} \mathrm{~F}_{5}\right), 137.8\left(\mathrm{dm},{ }^{1} J_{\mathrm{CF}}=255 \mathrm{~Hz}, \mathrm{C}_{6} \mathrm{~F}_{5}\right), 136.3\left(\mathrm{~s}, \mathrm{C}_{6} \mathrm{H}_{5}\right)$, $128.9\left(\mathrm{~s}, \mathrm{C}_{6} \mathrm{H}_{5}\right), 128.5\left(\mathrm{~s}, \mathrm{C}_{6} \mathrm{H}_{5}\right), 128.2\left(\mathrm{~s}, \mathrm{C}_{6} \mathrm{H}_{5}\right), 123.0(\mathrm{~s}, \mathrm{NCH}), 120.7(\mathrm{~s}, \mathrm{NCH}), 109.5\left(\mathrm{td},{ }^{2} J_{\mathrm{FC}}=16\right.$ $\mathrm{Hz},{ }^{4} J_{\mathrm{FC}}=4 \mathrm{~Hz}, \mathrm{C}_{6} \mathrm{~F}_{5}$ ipso $), 96.7\left(\mathrm{~d},{ }^{1} J_{\mathrm{RhC}}=7 \mathrm{~Hz}, \mathrm{C}_{5}\right), 55.3\left(\mathrm{~s}, \mathrm{NCH}_{2}\right), 44.2\left(\mathrm{~s}, \mathrm{NCH}_{2}\right), 9.5\left(\mathrm{~s}, \mathrm{CH}_{3}\right)$. $\delta_{\mathrm{F}}:-140.7\left(2 \mathrm{~F}, \mathrm{~m}, \mathrm{~F}_{\text {ortho }}\right),-151.4\left(1 \mathrm{~F}, \mathrm{t},{ }^{3} J_{\mathrm{FF}}=21 \mathrm{~Hz}, \mathrm{~F}_{\text {para }}\right),-159.9\left(2 \mathrm{~F}, \mathrm{~m}, \mathrm{~F}_{\text {meta }}\right)$.

1b: from $\left[\left(\eta^{5}-\mathrm{C}_{5} \mathrm{Me}_{5}\right) \operatorname{IrCl}(\mu-\mathrm{Cl})\right]_{2}(0.108 \mathrm{~g}, 0.136 \mathrm{mmol})$ and $\left[\left(\kappa \mathrm{C}-\mathrm{C}_{6} \mathrm{H}_{5} \mathrm{CH}_{2} \mathrm{NC}_{3} \mathrm{H}_{2} \mathrm{NCH}_{2} \mathrm{C}_{6} \mathrm{~F}_{5}\right) \mathrm{AgBr}\right]$ (0.143 g, $0.272 \mathrm{mmol})$. Yield: $0.172 \mathrm{~g}(86 \%)$. [M $-\mathrm{Cl}]^{+}:\left[\mathrm{C}_{27} \mathrm{H}_{26}{ }^{35} \mathrm{ClF}_{5}{ }^{193} \mathrm{IrN}_{2}\right]^{+}$requires 701.1407; found: 701.1355. $\delta_{\mathrm{H}}: 7.35\left(5 \mathrm{H}, \mathrm{m}, \mathrm{C}_{6} \mathrm{H}_{5}\right), 6.70\left(1 \mathrm{H}, \mathrm{d},{ }^{3} J_{\mathrm{HH}}=2.1 \mathrm{~Hz}, \mathrm{CH}\right), 6.50\left(1 \mathrm{H}, \mathrm{d},{ }^{3} J_{\mathrm{HH}}=2.1 \mathrm{~Hz}\right.$, $\mathrm{CH}), 6.08\left(1 \mathrm{H}, \mathrm{d},{ }^{2} J_{\mathrm{HH}}=14.9 \mathrm{~Hz}, \mathrm{NCHH}\right), 6.04\left(1 \mathrm{H}, \mathrm{d},{ }^{2} J_{\mathrm{HH}}=14.9 \mathrm{~Hz}, \mathrm{NCHH}\right), 5.55\left(1 \mathrm{H}, \mathrm{d},{ }^{2} J_{\mathrm{HH}}=\right.$ $15.9 \mathrm{~Hz}, \mathrm{NCH} H), 5.25\left(1 \mathrm{H}, \mathrm{d},{ }^{2} J_{\mathrm{HH}}=14.9 \mathrm{~Hz}, \mathrm{NCH} H\right), 1.69\left(15 \mathrm{H}, \mathrm{s}, \mathrm{CH}_{3}\right) . \delta_{\mathrm{C}}: 158.6\left(\mathrm{~s}, \mathrm{IrCN}_{2}\right), 145.8$ $\left(\mathrm{dm},{ }^{1} J_{\mathrm{CF}}=247 \mathrm{~Hz}, \mathrm{C}_{6} \mathrm{~F}_{5}\right), 141.7\left(\mathrm{dm},{ }^{1} J_{\mathrm{CF}}=256 \mathrm{~Hz}, \mathrm{C}_{6} \mathrm{~F}_{5}\right), 137.8\left(\mathrm{dm},{ }^{1} J_{\mathrm{CF}}=251 \mathrm{~Hz}, \mathrm{C}_{6} \mathrm{~F}_{5}\right), 136.4(\mathrm{~s}$, $\left.\mathrm{C}_{6} \mathrm{H}_{5}\right), 128.8\left(\mathrm{~s}, \mathrm{C}_{6} \mathrm{H}_{5}\right), 128.4\left(\mathrm{~s}, \mathrm{C}_{6} \mathrm{H}_{5}\right), 128.2\left(\mathrm{~s}, \mathrm{C}_{6} \mathrm{H}_{5}\right), 122.1(\mathrm{~s}, \mathrm{NCH}), 119.9$ (s, NCH), 110.0 (td, ${ }^{2} J_{\mathrm{FC}}=17 \mathrm{~Hz},{ }^{4} J_{\mathrm{FC}}=4 \mathrm{~Hz}, \mathrm{C}_{6} \mathrm{~F}_{5}$ ipso $), 89.4\left(\mathrm{~s}, \mathrm{C}_{5}\right), 55.0\left(\mathrm{~s}, \mathrm{NCH}_{2}\right), 43.5\left(\mathrm{~s}, \mathrm{NCH}_{2}\right), 9.2\left(\mathrm{~s}, \mathrm{CH}_{3}\right)$. $\delta_{\mathrm{F}}:-140.8\left(2 \mathrm{~F}, \mathrm{~m}, \mathrm{~F}_{\text {ortho }}\right),-151.5\left(1 \mathrm{~F}, \mathrm{t},{ }^{3} J_{\mathrm{FF}}=21 \mathrm{~Hz}, \mathrm{~F}_{\text {para }}\right),-160.0\left(2 \mathrm{~F}, \mathrm{~m}, \mathrm{~F}_{\text {meta }}\right)$.

2a from $\left.\left[\left(\eta^{5}-\mathrm{C}_{5} \mathrm{Me}\right)_{5}\right) \mathrm{RhCl}(\mu-\mathrm{Cl})\right]_{2}(0.086 \mathrm{~g}, 0.139 \mathrm{mmol})$ and $\left[\left(\kappa \mathrm{C}-\mathrm{C}_{6} \mathrm{H}_{5} \mathrm{CH}_{2} \mathrm{NC}_{3} \mathrm{H}_{2} \mathrm{NCH}_{2} \mathrm{C}_{6} \mathrm{~F}_{4} \mathrm{CF}_{3}-\right.\right.$ 4) $\mathrm{AgBr}](0.161 \mathrm{~g}, 0.279 \mathrm{mmol})$. Yield: $0.183 \mathrm{~g}(94 \%)$. Anal. Calc. for $\mathrm{C}_{28} \mathrm{H}_{26} \mathrm{Cl}_{2} \mathrm{~F}_{7} \mathrm{~N}_{2} \mathrm{Rh} \cdot\left(\mathrm{CH}_{2} \mathrm{Cl}_{2}\right)$ : $\mathrm{C}$, 44.5; H, 3.6; N, 3.6. Found: C, 44.5; H, 3.6; N, 3.6\%. $[\mathrm{M}-\mathrm{Cl}]^{+}:\left[\mathrm{C}_{28} \mathrm{H}_{26}{ }^{35} \mathrm{ClF}_{7} \mathrm{~N}_{2} \mathrm{Rh}\right]^{+}$requires 661.0728; found: 661.0843. $\delta_{\mathrm{H}} 7.37\left(5 \mathrm{H}, \mathrm{m}, \mathrm{C}_{6} \mathrm{H}_{5}\right), 6.81\left(1 \mathrm{H}, \mathrm{d},{ }^{3} J_{\mathrm{HH}}=2.1 \mathrm{~Hz}, \mathrm{CH}\right), 6.63\left(1 \mathrm{H}, \mathrm{d},{ }^{3} J_{\mathrm{HH}}\right.$ $=2.1 \mathrm{~Hz}, \mathrm{CH}), 6.16\left(2 \mathrm{H}, \mathrm{m}, \mathrm{NCHHC}_{6} \mathrm{H}_{5}\right.$ and $\left.\mathrm{NCHHC}_{6} \mathrm{~F}_{5}\right), 5.73(1 \mathrm{H}, \mathrm{m}, \mathrm{NCH} H), 5.33(1 \mathrm{H}, \mathrm{m}$, $\mathrm{NCH} H), 1.68\left(15 \mathrm{H}, \mathrm{s}, \mathrm{CH}_{3}\right) . \delta_{\mathrm{C}}: 172.9\left(\mathrm{~d},{ }^{1} J_{\mathrm{RhC}}=57 \mathrm{~Hz}, \mathrm{RhCN}_{2}\right), 145.6\left(\mathrm{dm},{ }^{1} J_{\mathrm{CF}}=241 \mathrm{~Hz}, \mathrm{C}_{6} \mathrm{~F}_{4}\right)$, $144.2\left(\mathrm{dm},{ }^{1} J_{\mathrm{CF}}=267 \mathrm{~Hz}, \mathrm{C}_{6} \mathrm{~F}_{4}\right), 136.2\left(\mathrm{~s}, \mathrm{C}_{6} \mathrm{H}_{5}\right), 128.9\left(\mathrm{~s}, \mathrm{C}_{6} \mathrm{H}_{5}\right), 128.4\left(\mathrm{~s}, \mathrm{C}_{6} \mathrm{H}_{5}\right), 128.3\left(\mathrm{~s}, \mathrm{C}_{6} \mathrm{H}_{5}\right)$, $123.3(\mathrm{~s}, \mathrm{NCH}), 121.0(\mathrm{~s}, \mathrm{NCH}), 120.5\left(\mathrm{q},{ }^{1} J_{\mathrm{CF}}=275 \mathrm{~Hz}, \mathrm{CF}_{3}\right), 119.2\left(\mathrm{t},{ }^{2} J_{\mathrm{CF}}=16 \mathrm{~Hz}, \mathrm{C}_{6} \mathrm{~F}_{4}\right.$ ipso $), 110.9$ $\left(\mathrm{m}, C \mathrm{CF}_{3}\right), 96.8\left(\mathrm{~d},{ }^{1} J_{\mathrm{RhC}}=7 \mathrm{~Hz}, \mathrm{C}_{5}\right), 55.3\left(\mathrm{~s}, \mathrm{NCH}_{2}\right), 44.9\left(\mathrm{~s}, \mathrm{NCH}_{2}\right), 9.5\left(\mathrm{CH}_{3}\right) . \delta_{\mathrm{F}}:-56.4\left(3 \mathrm{~F}, \mathrm{t},{ }^{4} J_{\mathrm{FF}}\right.$ $\left.=21 \mathrm{~Hz}, \mathrm{CF}_{3}\right),-138.7\left(2 \mathrm{~F}, \mathrm{~m}, \mathrm{C}_{6} \mathrm{~F}_{4}\right),-139.1\left(2 \mathrm{~F}, \mathrm{~m}, \mathrm{C}_{6} \mathrm{~F}_{4}\right)$. 
2b from $\left[\left(\eta^{5}-\mathrm{C}_{5} \mathrm{Me}_{5}\right) \operatorname{IrCl}(\mu-\mathrm{Cl})\right]_{2}(0.108 \mathrm{~g}, 0.136 \mathrm{mmol})$ and $\left[\left(\kappa \mathrm{C}-\mathrm{C}_{6} \mathrm{H}_{5} \mathrm{CH}_{2} \mathrm{NC}_{3} \mathrm{H}_{2} \mathrm{NCH}_{2} \mathrm{C}_{6} \mathrm{~F}_{4} \mathrm{CF}_{3}-\right.\right.$ 4)AgBr] (0.143 g, $0.272 \mathrm{mmol})$. Yield: $0.172 \mathrm{~g}(86 \%)$. [M $-\mathrm{Cl}]^{+}:\left[\mathrm{C}_{28} \mathrm{H}_{26}{ }^{35} \mathrm{ClF}_{7}{ }^{193} \mathrm{IrN}_{2}\right]^{+}$requires 751.1375; found: 751.1323. $\delta_{\mathrm{H}} 7.35\left(5 \mathrm{H}, \mathrm{m}, \mathrm{C}_{6} \mathrm{H}_{5}\right), 6.72\left(1 \mathrm{H}, \mathrm{d},{ }^{3} J_{\mathrm{HH}}=2.1 \mathrm{~Hz}, \mathrm{CH}\right), 6.57\left(1 \mathrm{H}, \mathrm{d},{ }^{3} J_{\mathrm{HH}}\right.$ $=2.1 \mathrm{~Hz}, \mathrm{CH}), 6.15\left(1 \mathrm{H}, \mathrm{d},{ }^{2} J_{\mathrm{HH}}=15.8 \mathrm{~Hz}, \mathrm{NCHH}\right), 6.05\left(1 \mathrm{H}, \mathrm{d},{ }^{2} J_{\mathrm{HH}}=14.9 \mathrm{~Hz}, \mathrm{NCHH}\right), 5.66(1 \mathrm{H}, \mathrm{d}$, $\left.{ }^{2} J_{\mathrm{HH}}=15.8 \mathrm{~Hz}, \mathrm{NCH} H\right), 5.25\left(1 \mathrm{H}, \mathrm{d},{ }^{2} J_{\mathrm{HH}}=14.9 \mathrm{~Hz}, \mathrm{NCH} H\right), 1.69\left(15 \mathrm{H}, \mathrm{s}, \mathrm{CH}_{3}\right) . \delta_{\mathrm{C}}: 159.2(\mathrm{~s}$, $\left.\operatorname{IrCN}_{2}\right), 145.6\left(\mathrm{dm},{ }^{1} J_{\mathrm{CF}}=239 \mathrm{~Hz}, \mathrm{C}_{6} \mathrm{~F}_{4}\right), 144.1\left(\mathrm{dm},{ }^{1} J_{\mathrm{CF}}=267 \mathrm{~Hz}, \mathrm{C}_{6} \mathrm{~F}_{4}\right), 136.3\left(\mathrm{~s}, \mathrm{C}_{6} \mathrm{H}_{5}\right), 128.9(\mathrm{~s}$, $\left.\mathrm{C}_{6} \mathrm{H}_{5}\right), 128.4\left(\mathrm{~s}, \mathrm{C}_{6} \mathrm{H}_{5}\right), 128.2\left(\mathrm{~s}, \mathrm{C}_{6} \mathrm{H}_{5}\right), 122.5(\mathrm{~s}, \mathrm{NCH}), 120.2(\mathrm{~s}, \mathrm{NCH}), 120.5\left(\mathrm{q},{ }^{1} J_{\mathrm{CF}}=275 \mathrm{~Hz}\right.$, $\left.\mathrm{CF}_{3}\right), 119.3\left(\mathrm{t},{ }^{2} J_{\mathrm{CF}}=16 \mathrm{~Hz}, \mathrm{C}_{6} \mathrm{~F}_{4}\right.$ ipso $), 110.6\left(\mathrm{~m}, \mathrm{CCF}_{3}\right), 89.5\left(\mathrm{~s}, \mathrm{C}_{5}\right), 55.0\left(\mathrm{~s}, \mathrm{NCH}_{2}\right), 44.1\left(\mathrm{~s}, \mathrm{NCH}_{2}\right)$, $9.2\left(\mathrm{CH}_{3}\right) . \delta_{\mathrm{F}}:-56.4\left(3 \mathrm{~F}, \mathrm{t},{ }^{4} J_{\mathrm{FF}}=21 \mathrm{~Hz}, \mathrm{CF}_{3}\right),-138.8\left(2 \mathrm{~F}, \mathrm{~m}, \mathrm{C}_{6} \mathrm{~F}_{4}\right),-139.2\left(2 \mathrm{~F}, \mathrm{~m}, \mathrm{C}_{6} \mathrm{~F}_{4}\right)$.

\subsection{X-ray crystallography}

Crystals of 1a, 1b, 2a and $\mathbf{2 b}$ were obtained from dichloromethane. Diffraction data were collected on an Agilent SuperNova, single source at offset, Atlas diffractometer with graphite-monochromated $\mathrm{Cu}-\mathrm{K}_{\alpha}$ radiation. The structures were solved using Olex2 [22] with olex2.solve [23] structure solution programme using Charge Flipping and refined with the olex2.refine [23] refinement package using Gauss-Newton minimization. All non-hydrogen atoms were refined with anisotropic thermal parameters, except for $C(1)-C(5), C(7)-C(10), C(13), C(15)$, $\mathrm{C}(16), \mathrm{C}(18), \mathrm{C}(21), \mathrm{C}(23), \mathrm{C}(24), \mathrm{N}(1)$ and $\mathrm{F}(23)$ of $\mathbf{2 b}$. Hydrogen atom positions were added in idealized positions and a riding model with fixed thermal parameters $(\mathrm{Uij}=1.2 \mathrm{Ueq}$ for the atom to which they are bonded (1.5 for $\left.\mathrm{CH}_{3}\right)$ ) was used for subsequent refinements. The function minimized was $\Sigma\left[\mathrm{w}\left(\left|F_{\mathrm{o}}\right|^{2}-\left|F_{\mathrm{c}}\right|^{2}\right)\right]$ with reflection weights $w^{-1}=\left[\sigma^{2}\left|F_{\mathrm{o}}\right|^{2}+(\mathrm{g} 1 P)^{2}+(\mathrm{g} 2 P)\right]$ where $P=\left[\max \left|F_{\mathrm{o}}\right|^{2}+\right.$ $\left.2\left|F_{\mathrm{c}}\right|^{2}\right] / 3$.

CCDC 1874162 (1a), 1874163 (1b), 1874164 (2a) and 1874165 (2b) contain the supplementary crystallographic data for this paper. These data can be obtained free of charge from The Cambridge Crystallographic Data Centre via www.ccdc.cam.ac.uk/data_request/cif.

\subsection{Density functional theory calculations}


DFT calculations were performed using Gaussian09 [24] with the long-range corrected functional $\omega \mathrm{B} 97 \mathrm{X}-\mathrm{D}[14]$ method and the $6-311 \mathrm{G}++(2 \mathrm{~d}, 2 \mathrm{p})$ basis set, except for the rhodium atom, for which LANL2DZ [25] was used. Harmonic vibrational frequencies were calculated to confirm that the optimized structures were indeed minima. The energies of interaction were calculated as the difference between the energy of the species and the sum of those of its components. All the $\mathrm{C}-\mathrm{H}$ bond distances were adjusted to $1.083 \AA$ [26] prior to single point energy calculations being undertaken.

\section{Acknowledgement}

We thank the University of Waikato for support and Dr J. Burrows for technical assistance. 


\section{References}

[1] (a) C.R. Patrick, G.S. Prosser, A Molecular Complex of Benzene and Hexafluorobenzene, Nature 187 (1960) 1021;

(b) C.K. Prout, J.D. Wright, Observations on the Crystal Structures of Electron Donor-Acceptor Complexes, Angew Chem., Int. Ed. 7 (1968) 659-667;

(c) T. Dahl, Crystal Structure of the 1:1 Complex Between Mesitylene and Hexafluorobenzene, Acta Chem. Scand. 25 (1971) 1031-1039.

[2] A. Hori, Arene-perfluoroarene interactions in coordination architectures, in E.R. Tiekink, J. Zukerman-Schpector (Eds.) The Importance of Pi-interactions in Crystal Engineering: Frontiers in Crystal Engineering, John Wiley \& Sons Ltd: Chichester, 2012, pp 163-185 (Chapter 7).

[3] a) S.V. Lindeman, V.G. Andrianov, S.G. Kravcheni, V.M. Potapov, K.A. Potekhin, Yu.T. Struchkov, Crystal and molecular structures of the two crystalline modifications on $\mathrm{N}$ salicylidene-pentafluoroaniline, Zh. Strukt. Khim. 22 (1981) 123-4.

b) G.W. Coates, A.R. Dunn, L.M. Henling, J.W. Ziller, E.B. Lobkovsky, R.H. Grubbs, Phenylperfluorophenyl stacking interactions: Topochemical[2+2] photodimerization and photopolymerization of olefinic compounds, J. Am. Chem. Soc. 120 (1998) 3641-3649.

c) J.R. Lane, G.C. Saunders, S.J. Webb, Engineering of a polar crystal structure exclusively by $\pi-\pi$ stacking between aryl and polyfluoroaryl groups, CrystEngComm 15 (2013) 1293-1295.

d) H.I. Althagbi, J.R. Lane, G.C. Saunders, S.J. Webb, Engineering Polar Crystal Structures by $\pi-\pi$ Stacking of $N$-Perfluoroarylbenzimidazoles, J. Fluorine Chem. 166 (2014) 88-95.

[4] J.M. Serrano-Becerra, S. Hernández-Ortega, D. Morales-Morales, J. Valdés-Martínez, Bottomup design and construction of a non-centrosymmetric network through $\pi-\pi$ stacking interactions, CrystEngComm 11 (2009) 226-228.

[5] G.C. Saunders, On the importance of $\pi-\pi$ stacking and cation-anion interactions in the construction of non-centrosymmetric networks of bromide salts of imidazolium cations bearing arene and polyfluoroarene rings, CrystEngComm 13 (2011) 1801-1803. 
[6] M.A. Oosterwijk, G.C. Saunders, W. Zou, Polyfluoroarene-Arene $\pi-\pi$ Stacking in Three Directions to provide Crystal Polarity, J. Fluorine Chem. 188 (2016) 80-84.

[7] H.I. Althagbi, A.J. Edwards, B.K. Nicholson, D.A. Reason, G.C. Saunders, S.A. Sim and D.A. van der Heijden, Arene-Perfluoroarene-Anion Stacking and Hydrogen Bonding Interactions in Imidazolium Salts for the Crystal Engineering of Polarity, Cryst. Growth Des. 16 (2016) 174188.

[8] M. Dinçer, N. Özdemir, S. Gülcemal, B. Çetinkaya, O. Büyükgüngör, Bromo( $\eta^{4}$-cycloocta-1,5diene)[1-(2,3,4,5,6-pentafluorobenzyl)-3-(2,4,6-trimethylbenzyl)benzimidazol-2-ylidene]rhodium(I), Acta Crystallogr., Sect. C: Cryst. Struct. Commun. 62 (2006) m252-m254.

[9] A.G. Gökçe, S. Gülcemal, M. Aygün, B. Çetinkaya, O. Büyükgüngör, trans-Bis[1-benzyl-3(2,3,4,5,6-pentafluorobenzyl)benzimidazol-2-ylidene]dibromopalladium(II), Acta Crystallogr., Sect. C: Cryst. Struct. Commun. 62 (2006) m535-m537.

[10] G. Rivera, O. Elizalde, G. Roa, I. Montiel, S. Bernès, Fluorinated N-heterocyclic carbenes rhodium (I) complexes and their activity in hydrosilylation of propargylic alcohols, J. Organomet. Chem. 699 (2012) 82-86.

[11] R.M. Reich, M. Cokoja, I.I.E. Markovits, C.J. Munchmeyer, M. Kaposi, A. Pöthig, W.A. Herrmann, F.E. Kühn, Influence of substituents on cation-anion contacts in imidazolium perrhenates, Dalton Trans. 44 (2015) 8669-8677.

[12] F.D. Bobbink, Z. Fei, R. Scopelliti, S. Das, P.J. Dyson, Functionalized Ionic (Poly)Styrenes and their Application as Catalysts in the Cycloaddition of $\mathrm{CO}_{2}$ to Epoxides, Helv. Chim. Acta 99 (2016) 821-829.

[13] S.R. Pachal, G.C. Saunders, J.K. Weston, Complex Dependent Regioselectivity in the Nucleophilic Substitution of Fluorine of a Coordinated Tetrafluoropyridyl N-Heterocycle Carbene, Inorg. Chim. Acta 394 (2013) 558-562.

[14] J.-D. Chai, M. Head-Gordon, Long-range corrected hybrid density functionals with damped atom-atom dispersion corrections, Phys. Chem. Chem. Phys. 10 (2008) 6615-6620.

[15] (a) A. Bondi, van der Waals Volumes and Radii, J. Phys. Chem. 68 (1964) 441-451. 
(b) R.S. Rowland, R. Taylor, Intermolecular Nonbonded Contact Distances in Organic Crystal Structures: Comparison with Distances Expected from van der Waals Radii, J. Phys. Chem. 100 (1996) 7384-7391.

[16] H. Amouri, J. Moussa, M. Malacria, V. Gandon, Cyclopentadienyl Ligands as Perfect Anion Receptors: Teamwork between $\pi$-Anion Interaction and $\mathrm{C}-\mathrm{H} \cdots$ Anion Hydrogen Bonds, Cryst. Growth Des. 9 (2009) 5304-5310.

[17] S. K. Singh, A. Das, The $n \rightarrow \pi^{*}$ interaction: a rapidly emerging non-covalent interaction, Phys. Chem. Chem. Phys. 17 (2015) 9596-9612.

[18] B.W. Gung, J.C. Amicangelo, Substituent Effects in $\mathrm{C}_{6} \mathrm{~F}_{6}-\mathrm{C}_{6} \mathrm{H}_{5} \mathrm{X}$ Stacking Interactions, J. Org. Chem. 71 (2006) 9261-9270.

[19] J.A. Zerkowski, J.C. MacDonald, C.T. Seto, D.A. Wierda, G.M. Whitesides, Design of Organic Structures in the Solid State: Molecular Tapes Based on the Network of Hydrogen Bonds Present in the Cyanuric Acid.Melamine Complex, J. Am. Chem. Soc. 116 (1994) 2382-2391.

[20] C. White, A. Yates, P.M. Maitlis, ( $\eta^{5}$-Pentamethylcyclopentadienyl)Rhodium and -Iridium Compounds, Inorg. Synth. 29 (1992) 228-234.

[21] S. McGrandle, G.C. Saunders, Group 9 Complexes of an N-Heterocycle Carbene bearing a Pentafluorobenzyl Substituent; Attempted Dehydrofluorinative Coupling of Cyclopentadienyl and N-Heterocycle Carbene Ligands, J. Fluorine Chem. 126 (2005) 449-453.

[22] O.V. Dolomanov, L.J. Bourhis, R.J. Gildea, J.A.K. Howard, H. Puschmann, OLEX2: a complete structure solution, refinement and analysis program, J. Appl. Cryst. 42 (2009) 339341.

[23] L.J. Bourhis, O.V. Dolomanov, R.J. Gildea, J.A.K. Howard, H. Puschmann, The anatomy of a comprehensive constrained, restrained refinement program for the modern computing environment - Olex2 dissected, Acta Crystallogr., A71 (2015) 59-75.

[24] M.J. Frisch, G.W. Trucks, H.B. Schlegel, G.E. Scuseria, M.A. Robb, J.R. Cheeseman, G. Scalmani, V. Barone, B. Mennucci, G.A. Petersson, H. Nakatsuji, M. Caricato, X. Li, H.P. Hratchian, A.F. Izmaylov, J. Bloino, G. Zheng, J.L. Sonnenberg, M. Hada, M. Ehara, K. Toyota, 
R. Fukuda, J. Hasegawa, M. Ishida, T. Nakajima, Y. Honda, O. Kitao, H. Nakai, T. Vreven, J.A. Montgomery Jr., J.E. Peralta, F. Ogliaro, M. Bearpark, J.J. Heyd, E. Brothers, K.N. Kudin, V.N. Staroverov, R. Kobayashi, J. Normand, K. Raghavachari, A. Rendell, J.C. Burant, S.S. Iyengar, J. Tomasi, M. Cossi, N. Rega, J.M. Millam, M. Klene, J.E. Knox, J.B. Cross, V. Bakken, C. Adamo, J. Jaramillo, R. Gomperts, R.E. Stratmann, O. Yazyev, A.J. Austin, R. Cammi, C. Pomelli, J.W. Ochterski, R.L. Martin, K. Morokuma, V.G. Zakrzewski, G.A. Voth, P. Salvador, J.J. Dannenberg, S. Dapprich, A.D. Daniels, Ö. Farkas, J.B. Foresman, J.V. Ortiz, J. Cioslowski, D.J. Fox, Gaussian 09, Revision A.2, Gaussian, Inc., Wallingford, CT, 2009.

[25] P.J. Hay, W.R. Wadt, Ab initio effective core potentials for molecular calculations - potentials for the transition-metal atoms Sc to Hg, J. Chem. Phys. 82 (1985) 270-83.

[26] F. H. Allen, O. Kennard, D. G. Watson, L. Brammer, A. G. Orpen, R. Taylor, in International Tables for Crystallography, ed. A. J. C. Wilson, Kluwer Academic, Dordrecht, 1995, vol. C, pp. 685-706. 


\section{Table 1}

Crystallographic data for ( $\eta^{5}$-pentamethylcyclopentadienyl)metal( $\kappa \mathrm{C}-1$-perfluoroarylmethyl-3-benzylimidazol-2-ylidene) dichloride complexes $\mathbf{1 a}$, 1b, 2a and $\mathbf{2} \mathbf{b}$. $^{\mathrm{a}}$

\begin{tabular}{|c|c|c|c|c|}
\hline & $1 \mathbf{a}$ & $\mathbf{1 b}$ & $2 \mathbf{2 a}$ & $2 \mathbf{b}$ \\
\hline Formula & $\mathrm{C}_{27} \mathrm{H}_{26} \mathrm{Cl}_{2} \mathrm{~F}_{5} \mathrm{~N}_{2} \mathrm{Rh}_{\text {. }} \mathrm{CH}_{2} \mathrm{Cl}_{2}$ & $\mathrm{C}_{27} \mathrm{H}_{26} \mathrm{Cl}_{2} \mathrm{~F}_{5} \mathrm{~N}_{2} \mathrm{Ir} \cdot \mathrm{CH}_{2} \mathrm{Cl}_{2}$ & $\mathrm{C}_{28} \mathrm{H}_{26} \mathrm{Cl}_{2} \mathrm{~F}_{7} \mathrm{~N}_{2} \mathrm{Rh}_{.} \mathrm{CH}_{2} \mathrm{Cl}_{2}$ & $\mathrm{C}_{28} \mathrm{H}_{26} \mathrm{Cl}_{2} \mathrm{~F}_{7} \mathrm{~N}_{2} \mathrm{Ir} . \mathrm{CH}_{2} \mathrm{Cl}_{2}$ \\
\hline Formula weight & 732.26 & 821.57 & 782.26 & 871.57 \\
\hline Crystal system & orthorhombic & orthorhombic & orthorhombic & orthorhombic \\
\hline Space group & $P 2_{1} 2_{1} 2_{1}$ & $P 2_{1} 2_{1} 2_{1}$ & $P \mathrm{ca}_{1}$ & $P \mathrm{ca} 2_{1}$ \\
\hline$a, \AA$ & $10.60874(18)$ & $10.6467(2)$ & $16.3955(4)$ & $16.3938(3)$ \\
\hline$b, \AA$ & $15.6614(2)$ & 15.6791(3) & $10.75786(16)$ & 10.7913(3) \\
\hline$c, \AA$ & $17.5915(3)$ & $17.5997(4)$ & 17.3761(4) & $17.3948(4)$ \\
\hline$V, \AA^{3}$ & $2922.78(8)$ & 2937.94(10) & $3064.8(1)$ & $3077.31(12)$ \\
\hline Z & 4 & 4 & 4 & 4 \\
\hline$D_{\mathrm{c}}\left(\mathrm{g} \mathrm{cm}^{-3}\right)$ & 1.664 & 1.8573 & 1.695 & 1.8811 \\
\hline Crystal size $\left(\mathrm{mm}^{3}\right)$ & $0.142 \times 0.088 \times 0.060$ & $0.189 \times 0.082 \times 0.029$ & $0.109 \times 0.052 \times 0.031$ & $0.317 \times 0.063 \times 0.044$ \\
\hline$\mu\left(\mathrm{mm}^{-1}\right)$ & 8.571 & 12.625 & 8.316 & 12.195 \\
\hline
\end{tabular}




\begin{tabular}{|c|c|c|c|c|}
\hline$\theta$ range $\left(^{\circ}\right)$ & $3.78-73.88$ & $3.78-74.02$ & $4.11-74.00$ & $4.10-73.81$ \\
\hline Total reflections & 15608 & 8718 & 15692 & 9352 \\
\hline Unique reflections $\left(R_{\text {int }}\right)$ & $5775(0.0394)$ & $4916(0.0299)$ & $5580(0.0483)$ & $4933(0.0318)$ \\
\hline Observed reflections $[I>2 \sigma(I)]$ & 5264 & 4430 & 4845 & 4562 \\
\hline Parameters & 366 & 361 & 393 & 303 \\
\hline Final $R$ indices $[I>2 \sigma(I)]$ & $\begin{array}{l}R_{1}=0.0334, \\
w R_{2}=0.0746\end{array}$ & $\begin{array}{l}R_{1}=0.0305 \\
w R_{2}=0.0367\end{array}$ & $\begin{array}{l}R_{1}=0.0466 \\
w R_{2}=0.1196\end{array}$ & $\begin{array}{l}R_{1}=0.0482, \\
w R_{2}=0.1453\end{array}$ \\
\hline$R$ indices (all data) & $\begin{array}{l}R_{1}=0.0464, \quad w R_{2}= \\
0.0792\end{array}$ & $\begin{array}{l}R_{1}=0.0735, \\
w R_{2}=0.0771\end{array}$ & $\begin{array}{l}R_{1}=0.0564, \\
w R_{2}=0.1268\end{array}$ & $\begin{array}{l}R_{1}=0.0547 \\
w R_{2}=0.1510\end{array}$ \\
\hline Weighting scheme & $\begin{array}{l}w=1 /\left[\sigma^{2}\left(F_{\mathrm{o}}\right)^{2}+\{0.0370\right. \\
\left.\left(F_{\mathrm{o}}^{2}+2 F_{\mathrm{c}}^{2}\right) / 3\right\}^{2}+3.6990 \\
\left.\left(F_{\mathrm{o}}^{2}+2 F_{\mathrm{c}}^{2}\right) / 3\right]\end{array}$ & $\begin{array}{l}w=1 /\left[\sigma^{2}\left(F_{\mathrm{o}}\right)^{2}+\left\{0.0400\left(F_{\mathrm{o}}^{2}\right.\right.\right. \\
\left.\left.\left.+2 F_{\mathrm{c}}^{2}\right) / 3\right\}^{2}\right]\end{array}$ & $\begin{array}{l}w=1 /\left[\sigma^{2}\left(F_{\mathrm{o}}\right)^{2}+\{0.0860\right. \\
\left.\left.\left(F_{\mathrm{o}}^{2}+2{F_{\mathrm{c}}}^{2}\right) / 3\right\}^{2}\right]\end{array}$ & $\begin{array}{l}w=1 /\left[\sigma^{2}\left(F_{\mathrm{o}}\right)^{2}+162.8190\right. \\
\left.\left(F_{\mathrm{o}}^{2}+2 F_{\mathrm{c}}^{2}\right) / 3\right]\end{array}$ \\
\hline Max., min. $\Delta \rho\left(\mathrm{e}^{\circ}{ }^{-3}\right)$ & $1.182,-1.201$ & $1.079,-1.246$ & $1.573,-0.640$ & $2.739,-1.541$ \\
\hline Goodness of fit on $F^{2}$ & 1.049 & 1.0326 & 1.025 & 1.038 \\
\hline Flack parameter & $-0.022(8)$ & $-0.005(11)$ & $0.007(12)$ & $-0.04(2)$ \\
\hline & & & & \\
\hline
\end{tabular}


${ }^{a}$ Estimated standard deviations are given in parentheses. 
Table 2 Selected distances $(\AA)$ and angles $\left(^{\circ}\right)$ for $\left(\eta^{5}\right.$-pentamethylcyclopentadienyl)metal( $(\kappa C-1$-perfluoroarylmethyl-3-benzylimidazol-2-ylidene) dichloride complexes 1a, 1b, $\mathbf{2 a}$ and $\mathbf{2 b}{ }^{\mathrm{a}}{ }^{2}$

\begin{tabular}{|c|c|c|c|c|c|c|}
\hline & $1 \mathrm{a}$ & & $1 \mathrm{~b}$ & $2 \mathbf{a}$ & & $2 \mathbf{b}$ \\
\hline & Experimental & Calculated $^{\text {b }}$ & Experimental & Experimental & Calculated $^{\mathrm{b}}$ & Experimental \\
\hline $\mathrm{Cp} *-\mathrm{M}$ & $1.805(4)$ & 1.822 & $1.802(7)$ & $1.809(7)$ & 1.821 & $1.82(2)$ \\
\hline $\mathrm{M}-\mathrm{Cl}(1)$ & $2.4715(9)$ & 2.444 & $2.4152(14)$ & $2.4716(14)$ & 2.446 & $2.474(3)$ \\
\hline $\mathrm{M}-\mathrm{Cl}(2)$ & $2.4023(9)$ & 2.423 & $2.4786(13)$ & $2.4009(14)$ & 2.421 & $2.410(3)$ \\
\hline $\mathrm{M}-\mathrm{C}(11)$ & $2.069(4)$ & 2.050 & $2.056(6)$ & $2.061(5)$ & 2.050 & $2.075(12)$ \\
\hline $\mathrm{C}(11)-\mathrm{N}(1)$ & $1.361(5)$ & 1.354 & $1.363(7)$ & $1.355(9)$ & 1.355 & $1.36(2)$ \\
\hline $\mathrm{N}(1)-\mathrm{C}(21)$ & $1.464(5)$ & 1.449 & $1.453(8)$ & $1.483(10)$ & 1.445 & 1.471(19) \\
\hline $\mathrm{C}(21)-\mathrm{C}(22)$ & $1.513(5)$ & 1.508 & $1.511(8)$ & $1.515(9)$ & 1.508 & $1.51(2)$ \\
\hline $\mathrm{C}(11)-\mathrm{N}(2)$ & $1.354(5)$ & 1.351 & $1.351(8)$ & $1.359(9)$ & 1.350 & $1.35(2)$ \\
\hline $\mathrm{N}(2)-\mathrm{C}(14)$ & $1.464(5)$ & 1.462 & $1.483(8)$ & $1.484(9)$ & 1.463 & $1.476(19)$ \\
\hline$C(14)-C(15)$ & $1.507(6)$ & 1.507 & $1.488(10)$ & $1.529(9)$ & 1.507 & $1.48(2)$ \\
\hline $\mathrm{Cl}(1) \cdots \mathrm{C}(21)$ & $3.232(5)$ & 3.230 & $3.227(6)$ & $3.373(7)$ & 3.217 & $3.37(2)$ \\
\hline $\mathrm{Cl}(2) \cdots \mathrm{C}(14)$ & $3.283(5)$ & 3.308 & $3.287(7)$ & $3.310(7)$ & 3.302 & $3.34(1)$ \\
\hline
\end{tabular}




\begin{tabular}{|c|c|c|c|c|c|c|}
\hline $\mathrm{Cp} *-\mathrm{M}-\mathrm{Cl}(1)$ & $119.6(1)$ & 121.9 & $120.3(2)$ & $120.7(2)$ & 121.8 & $121.7(4)$ \\
\hline $\mathrm{Cp}^{*}-\mathrm{M}-\mathrm{Cl}(2)$ & $124.5(1)$ & 123.0 & $125.5(2)$ & $124.4(2)$ & 123.5 & $125.1(4)$ \\
\hline $\mathrm{Cp} *-\mathrm{M}-\mathrm{C}(11)$ & $128.5(2)$ & 126.0 & $128.9(3)$ & $124.7(2)$ & 126.0 & $125.1(6)$ \\
\hline $\mathrm{Cl}(1)-\mathrm{M}-\mathrm{Cl}(2)$ & $88.77(3)$ & 89.67 & $86.68(5)$ & $88.85(5)$ & 89.39 & $86.6(1)$ \\
\hline $\mathrm{C}(11)-\mathrm{M}-\mathrm{Cl}(1)$ & $95.2(1)$ & 93.8 & $94.4(2)$ & $97.0(2)$ & 93.7 & $96.6(5)$ \\
\hline $\mathrm{C}(11)-\mathrm{M}-\mathrm{Cl}(2)$ & $89.9(1)$ & 93.0 & $89.6(2)$ & $92.33(17)$ & 92.9 & $91.8(5)$ \\
\hline $\mathrm{M}-\mathrm{C}(11)-\mathrm{N}(1)$ & $126.5(3)$ & 126.9 & $127.3(5)$ & $127.9(5)$ & 126.5 & $127(1)$ \\
\hline $\mathrm{M}-\mathrm{C}(11)-\mathrm{N}(2)$ & $128.9(3)$ & 128.4 & $128.6(4)$ & $125.9(5)$ & 128.8 & $126(1)$ \\
\hline $\mathrm{N}(1)-\mathrm{C}(11)-\mathrm{N}(2)$ & $104.5(3)$ & 104.1 & $104.1(5)$ & $103.2(5)$ & 104.1 & 104(1) \\
\hline $\mathrm{C}(11)-\mathrm{N}(1)-\mathrm{C}(21)$ & $124.3(3)$ & 126.4 & $124.1(5)$ & $126.6(6)$ & 126.3 & $127(1)$ \\
\hline $\mathrm{N}(1)-\mathrm{C}(21)-\mathrm{C}(22)$ & $112.6(3)$ & 113.3 & $112.5(5)$ & $108.5(5)$ & 114.4 & $110(1)$ \\
\hline $\mathrm{C}(11)-\mathrm{N}(2)-\mathrm{C}(14)$ & $127.2(3)$ & 127.3 & $127.9(5)$ & $127.6(5)$ & 127.3 & $129(1)$ \\
\hline$N(2)-C(14)-C(15)$ & $112.3(3)$ & 111.5 & $112.7(6)$ & $109.4(5)$ & 111.2 & 111(1) \\
\hline $\mathrm{Cp} *-\mathrm{M}-\mathrm{C}(11)-\mathrm{N}(1)$ & $88.4(4)$ & 84.8 & $88.9(8)$ & $-82.1(7)$ & 84.2 & $84(2)$ \\
\hline $\mathrm{Cp} *-\mathrm{M}-\mathrm{C}(11)-\mathrm{N}(2)$ & $-89.3(4)$ & -84.5 & $-90.0(7)$ & $74.8(6)$ & -85.3 & $-76(2)$ \\
\hline
\end{tabular}




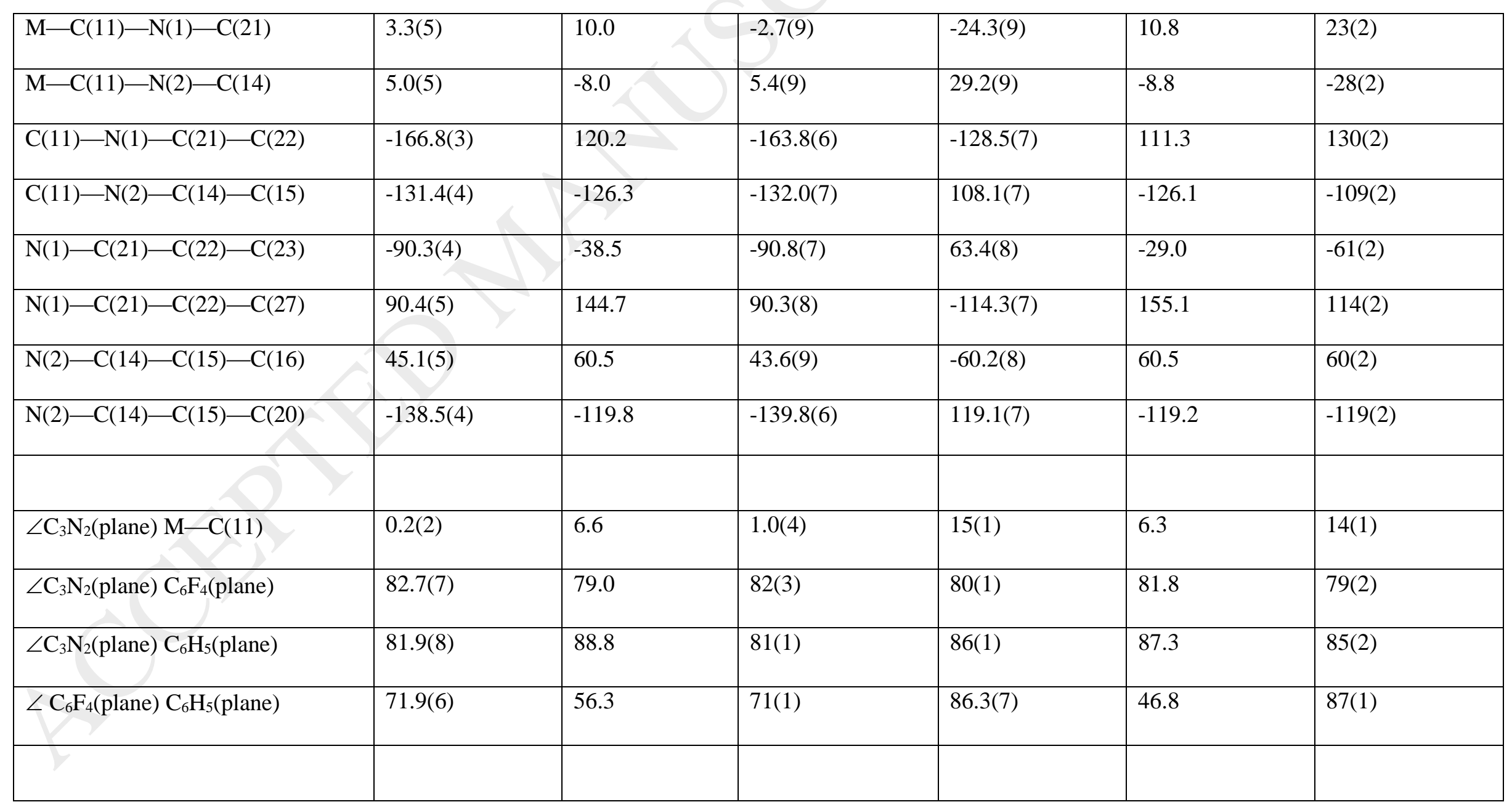

${ }^{a}$ Estimated standard deviations are given in parentheses. Cp* indicates the centroid of the five carbon atoms of the cyclopentadienyl ring. ${ }^{\mathrm{b}}$ Calculated using the $\omega \mathrm{B} 97 \mathrm{X}-\mathrm{D}[14]$ method with the 6-311G++(2d,2p) basis set, except for the rhodium atom, for which LANL2DZ [25] was used. 
Table 3 Selected intermolecular distances $(\AA)$ and angles $\quad\left(^{\circ}\right)$ between dichloromethane and

$\left(\eta^{5}\right.$-pentamethylcyclopentadienyl)metal( $\kappa \mathrm{C}-1$-perfluoroarylmethyl-3-benzylimidazol-2-ylidene) dichloride complexes 1a, 1b, 2a and $\mathbf{2 b}{ }^{\mathrm{a}}$

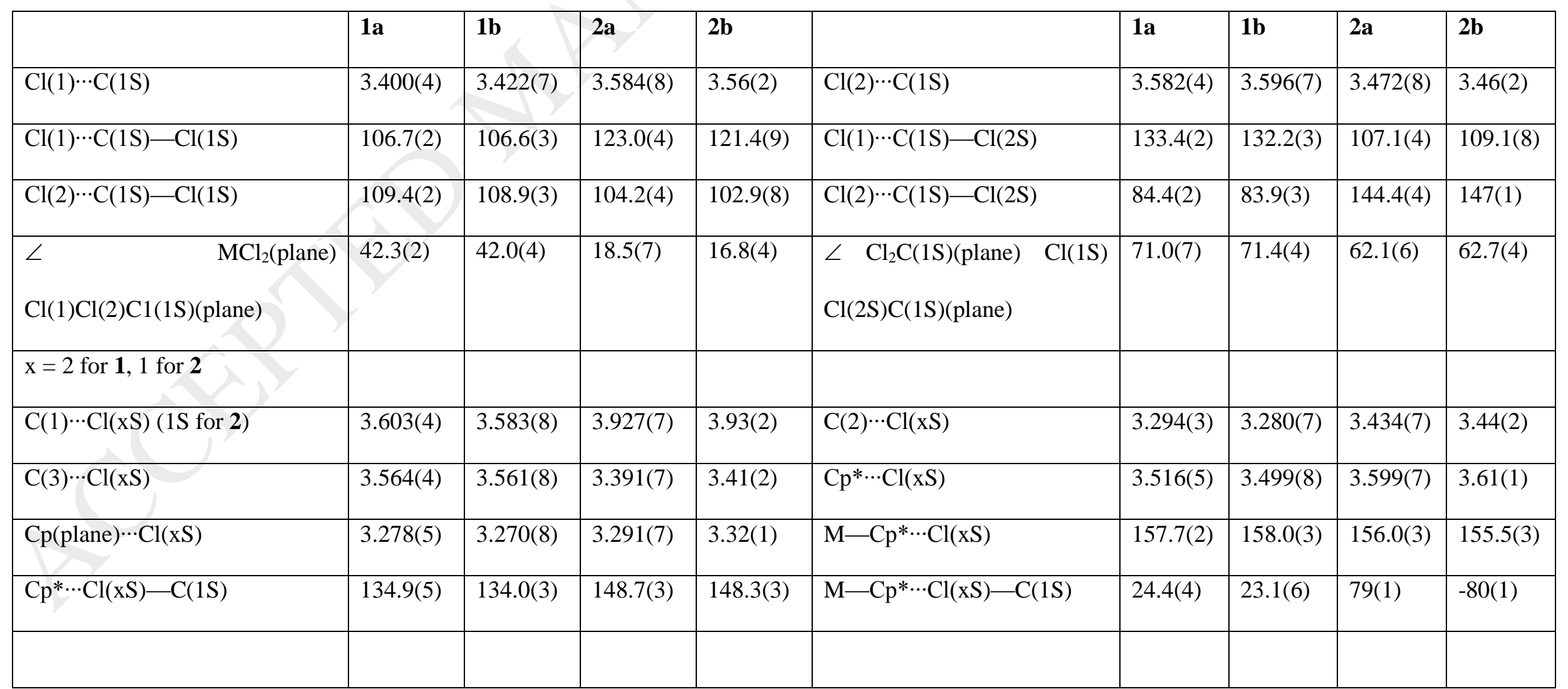

${ }^{a}$ Estimated standard deviations are given in parentheses. $\mathrm{Cp}^{*}$ indicates the centroid of the five carbon atoms of the cyclopentadienyl ring. 
Table 4 Selected intermolecular distances $(\AA)$ and angles $\quad\left({ }^{\circ}\right)$ between molecules

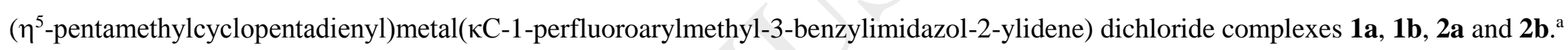

\begin{tabular}{|c|c|c|c|c|c|}
\hline & $1 \mathbf{a}$ & $1 \mathrm{~b}$ & & $2 a$ & $2 b$ \\
\hline $\mathrm{Cl}(1) \cdots \mathrm{C}(13)^{\prime}$ & $3.627(5)$ & $3.643(6)$ & $\mathrm{Cl}(1) \cdots \mathrm{C}(12)^{\prime}$ & $3.786(7)$ & $3.80(1)$ \\
\hline $\mathrm{M}-\mathrm{Cl}(1) \cdots \mathrm{C}(13)^{\prime}$ & $111.34(7)$ & $112.5(1)$ & $\mathrm{M}-\mathrm{Cl}(1) \cdots \mathrm{C}(12)^{\prime}$ & $90.8(1)$ & $91.3(2)$ \\
\hline $\mathrm{Cl}(1) \cdots \mathrm{C}(13)^{\prime}-\mathrm{N}(2)^{\prime}$ & $159.2(3)$ & $160.3(4)$ & $\mathrm{Cl}(1) \cdots \mathrm{C}(12)^{\prime}-\mathrm{N}(1)^{\prime}$ & $132.8(4)$ & $133(1)$ \\
\hline $\mathrm{Cl}(1)^{\cdots} \mathrm{C}(13)^{\prime}-\mathrm{C}(12)^{\prime}$ & $92.7(3)$ & $92.3(4)$ & $\mathrm{Cl}(1)^{\cdots} \mathrm{C}(12)^{\prime}-\mathrm{C}(13)^{\prime}$ & $121.7(5)$ & $120(1)$ \\
\hline $\mathrm{Cl}(2) \cdots \mathrm{C}(12)^{\prime}$ & $3.571(4)$ & $3.590(7)$ & $\mathrm{Cl}(2) \cdots \mathrm{C}(13)^{\prime}$ & $3.317(7)$ & $3.32(2)$ \\
\hline $\mathrm{M}-\mathrm{Cl}(2) \cdots \mathrm{C}(12)^{\prime}$ & $105.03(7)$ & $105.6(1)$ & $\mathrm{M}-\mathrm{Cl}(2) \cdots \mathrm{C}(13)^{\prime}$ & $110.2(1)$ & $110.3(3)$ \\
\hline $\mathrm{Cl}(2) \cdots \mathrm{C}(12)^{\prime}-\mathrm{N}(1)^{\prime}$ & $132.9(3)$ & $132.4(4)$ & $\mathrm{Cl}(2) \cdots \mathrm{C}(13)^{\prime}-\mathrm{N}(2)^{\prime}$ & $154.3(4)$ & 154(1) \\
\hline $\mathrm{Cl}(2) \cdots \mathrm{C}(12)^{\prime}-\mathrm{C}(13)^{\prime}$ & $121.3(1)$ & $120.7(4)$ & $\mathrm{Cl}(2) \cdots \mathrm{C}(13)^{\prime}-\mathrm{C}(12)^{\prime}$ & $88.5(4)$ & $88(1)$ \\
\hline $\mathrm{Cl}(2) \cdots \mathrm{C}(23)^{\prime}$ & $3.375(4)$ & $3.374(7)$ & $\mathrm{Cl}(1)^{\cdots} \mathrm{C}(26)^{\prime}$ & $3.785(8)$ & $3.80(2)$ \\
\hline $\mathrm{Cl}(2) \cdots \mathrm{C}(24)^{\prime}$ & $3.128(4)$ & $3.122(7)$ & $\mathrm{Cl}(1)^{\cdots \cdots} \mathrm{C}(27)^{\prime}$ & $3.699(7)$ & $3.72(2)$ \\
\hline $\mathrm{Cl}(2) \cdots \mathrm{C}_{6} \mathrm{~F}^{\prime *}$ & $3.375(5)$ & $3.383(8)$ & $\mathrm{Cl}(1) \cdots \mathrm{C}_{6} \mathrm{~F}^{\prime *}$ & $4.211(8)$ & $4.23(2)$ \\
\hline $\mathrm{M}-\mathrm{Cl}(2) \cdots \mathrm{C}_{6} \mathrm{~F}^{\prime *}$ & $163.5(3)$ & $163(1)$ & $\mathrm{M}-\mathrm{Cl}(1) \cdots \mathrm{C}_{6} \mathrm{~F}^{\prime *}$ & $121.4(1)$ & $121.0(3)$ \\
\hline
\end{tabular}




\begin{tabular}{|c|c|c|c|c|c|}
\hline$\angle \mathrm{MCl}_{2}$ (plane) $\mathrm{Cl}_{2} \mathrm{C}_{2}$ (plane) & $41.0(1)$ & $41.6(1)$ & $\angle \mathrm{MCl}_{2}($ plane $) \mathrm{Cl}_{2} \mathrm{C}_{2}$ (plane) & $53.7(1)$ & $54.9(3)$ \\
\hline$\angle \mathrm{Cl}_{2} \mathrm{C}_{2}$ (plane) $\mathrm{C}_{3} \mathrm{~N}_{2}{ }^{\prime}($ plane $)$ & $3.9(3)$ & $3.9(4)$ & $\angle \mathrm{Cl}_{2} \mathrm{C}_{2}($ plane $) \mathrm{C}_{3} \mathrm{~N}_{2}^{\prime}($ plane $)$ & $22.0(4)$ & $23(1)$ \\
\hline & & & $\mathrm{C}_{6} * \ldots \mathrm{C}_{6} \mathrm{~F}^{*}$ & $3.95(1)$ & $3.93(3)$ \\
\hline & & & $\mathrm{C}_{6} * \ldots \mathrm{C}_{6} \mathrm{~F}^{\prime}($ plane $)$ & $3.39(1)$ & $3.38(3)$ \\
\hline & & & $\mathrm{C}_{6}($ plane $) \cdots \mathrm{C}_{6} \mathrm{~F}^{\prime *}$ & $3.79(1)$ & $3.76(3)$ \\
\hline & & & $\angle \mathrm{C}_{6}($ plane $) \mathrm{C}_{6} \mathrm{~F}^{\prime}($ plane $)$ & $16.6(5)$ & $16(1)$ \\
\hline & & & $\mathrm{Cl}(2) \cdots \mathrm{C}_{6} \mathrm{~F}^{\prime *}$ & $4.024(7)$ & $4.06(2)$ \\
\hline & . & & $\mathrm{Cl}(2) \cdots \mathrm{C}(26)^{\prime}$ & $3.351(7)$ & $3.37(2)$ \\
\hline & & & $\mathrm{Cl}(2) \cdots \mathrm{C}(27)^{\prime}$ & $3.510(7)$ & $3.53(2)$ \\
\hline
\end{tabular}

${ }^{a}$ Estimated standard deviations are given in parentheses. $\mathrm{C}_{6}$ and $\mathrm{C}_{6} \mathrm{~F}^{\prime}$ represent the phenyl and polyfluorophenyl rings respectively. $\mathrm{C}_{6} \mathrm{~F}^{\prime *}$ indicates the centroid of the six carbon atoms of the trifluoromethyltetrafluorophenyl ring. 